Amasya Illahiyat Dergisi - Amasya Theology Journal

ISSN 2667-7326 | e-ISSN 2667-6710

Aralık / December 2020, 15: 143-177

\title{
Rivayetlerin Muhafazasına ve Nakline Yönelik Entelektüel Bir İlgi: İmlâ Usûlü ve Hadis Literatürüne Yansımaları
}

\author{
Mustafa TANRIVERDí \\ Dr. Öğr. Üyesi, Muğla Sıtkı Koçman Üniversitesi, İslami İlimler Fakültesi, \\ Hadis Anabilim Dalı \\ Assistant Professor, Muğla Sitkı Koçman University, \\ Faculty of Islamic Sciences, Department of Hadith \\ Muğla, Turkey \\ mustafatanriverdi@mu.edu.tr \\ orcid.org/0000-0003-3329-0019
}

\section{Makale Bilgisi / Article Information}

Makale Türü / Article Types: Araştırma Makalesi / Research Article

Geliş Tarihi / Received: 27 Temmuz / July 2020

Kabul Tarihi / Accepted: 05 Ekim / October 2020

Yayın Tarihi / Published: 30 Aralık / December 2020

Yayın Sezonu / Pub. Date Season: Aralık / December

Sayı / Issue: 15 Sayfa / Pages: 143-177

Atıf / Cite as: Tanrıverdi, Mustafa. "Rivayetlerin Muhafazasına ve Nakline Yönelik Entelektüel Bir İlgi: İmlâ Usûlü ve Hadis Literatürüne Yansımaları [An Intellectual Interest for the Protection and Narration of Hadiths: The Method of Imlā and Its Reflections to Hadith Literature]". Amasya Ilahiyat Dergisi-Amasya Theology Journal 15 (December 2020): 143-177.

https://doi.org/10.18498/amailad.774429.

Intihal / Plagiarism: Bu makale, en az iki hakem tarafından incelendi ve intihal içermediği teyit edildi. / This article has been reviewed by at least two referees and scanned via a plagiarism software.

Copyright (C Published by Amasya Üniversitesi, İlahiyat Fakültesi / Amasya University, Faculty of Theology, Amasya, 05100 Turkey. All rights reserved. https://dergipark.org.tr/amailad. 
144 | M. TANRIVERDİ / Rivayetlerin Muhafazasına ve Nakline Yönelik Entelektüel Bir İlgi:

İmlâ Usûlü ve Hadis Literatürüne Yansımaları

An Intellectual Interest for the Protection and Narration of Hadiths: The Method of Imlā and Its Reflections to Hadith Literature

\section{Abstract}

Discussions about the beginning of the writing the hadiths are very important in terms of enabling to determine a time period in which the important determinations will be based on the history of the hadith. Especially, the existence of narrations that can be used as evidence against and in favor of this issue makes this debate even more meaningful. In fact, the interest in the hadith has led to efforts to transfer this knowledge both orally and in writing from the early periods of the hadith history. Although it is noted that from the earliest times, as a result of the reliance on memory rather than writing, a reflex against writing hadith has remained in existence for a certain period of time, but it is understood that the activities on hadith writing have found a wide scope of practice and oral tradition left its place to written culture in the subsequent process of time. In this context, efforts towards written narrations have brought the writing to the fore fore as the prevailing element in the preservation and transmission of hadiths over time. One of the efforts in this direction is the imla activities that begin between the teacher and the student, and has became widespread intellectual interest in the process. Imlā is a reliable method of the reception of hadith based on the fact that the material subject to the narration is written under the supervision of the shaykh himself in accordance with a number of rules and corrected it by checking on the original copy.

This method, the first examples of which were seen in the period of the Prophet Muhammad (pbuh), started to be seen technically in the $2^{\text {nd }}$ century (8.). In the middle of this century, Hadith imlā activities, which gained momentum, had become one of the important ways of hadith reception and transmission. These activities, which has attracted the attention of very large groups since the $3^{\text {rd }}$ century (9.) has continued for a long time. During these periods, Imlā sessions, which are not determined as a special meeting place, were organized in mosque, market, bazaar, streets and avenues and in the $5^{\text {th }}$ century (11.), it began to organized in madrasas and dār al-hadīth, which were the science centers of the period. In addition, such scientific institutions built in different regions with the special incentives of the state officials in this process have given a more systematic identity to the imlā sessions in terms of the place and time of meeting. Imlā meetings, which were accepted by the people as well as the muhaddiths; have been organized in many regions such as Baghdad, Basra, 
M. TANRIVERDİ / An Intellectual Interest for the Protection and Narration of Hadiths: The Method of Imlā and Its Reflections to Hadith Literature | 145

Damascus, Medina, Qazvin, Isfahan, Herat, Merv and Nishapur. In addition, the participation of large masses in the meetings led to increase the intellectual curiosity towards imlā activities and enriched the hadith culture of these regions.

In this context, imlā sessions have also ensured the formation of a social fabric by bringing together different segments of society from scholars to politicians on a common ground of "hadith". Moreover, with this method, which plays an important role in the written narration and preservation of the hadiths, a remarkable literature has emerged in the hadith literature thanks to extensive participation to the imla sessions concluded in various regions since the early periods. During these sessions, a large number of literary works in different genres and sizes named as juz', madjlis and amālī were created, as a result of these activities it made a significant contribution to the hadith literature and culture.

By the $10^{\text {th }}$ century (16.), the activities of imlā lost its former importance due to various reasons such as the increasing reliance on books with the effect of the changing in the understanding on science and culture of the period, the collection of hadiths the understanding on science and culture of the period, the becoming large extent, and the decreasing in hadith the hafizes and enthusiastic students. In this study, the historical aspect of imlā method which arouses intellectual curiosity on almost every segment of the society that interested in hadith, from scholars to politicians as well as muhaddiths, and the reflections of imlā activities on the history of hadith literature and history were examined.

Keywords: Hadith, Narration, Writing, Imlā, Amālī.

\section{Rivayetlerin Muhafazasına ve Nakline Yönelik Entelektüel Bir İlgi: İmlâ Usûlü ve Hadis Literatürüne Yansımaları}

\section{Öz}

Hadislerin yazımının başlangıcına dair tartışmalar, hadis tarihi açısından önemli tespitlerin üzerine inşa edileceği bir zaman dilimini saptamaya imkân tanıması bakımından oldukça önemlidir. Özellikle bu konuda lehte ve aleyhte delil olarak kullanılabilecek birtakım rivayetlerin bulunması, bu tartışmayı daha da anlamlı kılmaktadır. Öyle ki hadise duyulan ilgi, hadis tarihinin erken dönemlerinden itibaren bu ilmin gerek sözlü gerekse yazılı nakline dönük çabaları beraberinde getirmiştir. İlk dönemlerden itibaren yazıdan ziyade hafızaya olan güven geleneğinin bir sonucu olarak belli bir müddet hadis 
146 | M. TANRIVERDİ / Rivayetlerin Muhafazasına ve Nakline Yönelik Entelektüel Bir İlgi: İmlâ Usûlü ve Hadis Literatürüne Yansımaları

yazımına karşı bir refleksin varlığını koruduğu kaydını koymakla birlikte hadis yazma faaliyetlerinin ilerleyen süreçte büyük ölçüde tatbik sahası bulduğu ve sözlü geleneğin yerini yazılı kültüre bıraktı̆̆ı anlaşılmaktadır. Bu bağlamda yazılı rivayete yönelik çabalar, zamanla hadislerin muhafazasında ve naklinde yazının hâkim unsur olarak ön plana çıkmasını sağlamıştır. Bu minvaldeki çabalardan biri de hoca ile talebe arasında başlayan ve süreç içerisinde yaygınlaşarak entelektüel bir ilgiye dönüşen imlâ faaliyetleridir. İmlâ, rivayete konu olan malzemenin birtakım kurallara uygun olarak bizzat hocanın nezaretinde yazılması ve asıl nüsha üzerinden kontrol edilerek tashih edilmesi esasına dayanan güvenilir bir hadis tahammül yöntemidir.

Hz. Peygamber (s.a.v) döneminde ilk nüvelerine rastlanan bu usûl, teknik anlamda 2. (8.) yüzyılla birlikte görülmeye başlamıştır. Bu asrın ortalarına gelindiğinde hız kazanan hadis imlâ faaliyetleri, hadis tahammül ve naklinin önemli araçlarından biri haline gelmiştir. 3. (9.) yüzyıldan itibaren oldukça kalabalık grupların ilgisine mazhar olan imlâ ameliyesi uzun müddet varlığını sürdürmüştür. Bu dönemlerde müstakil bir toplanma yeri belirlenmeyen imlâ oturumları mescid, çarşı, pazar, sokak ve caddelerde düzenlenmiş olup 5. (11.) yüzyılla birlikte kendi dönemlerinin ilim merkezleri olan medrese ve dârülhadîslerde yapılmaya başlanmıştır. Ayrıca bu süreçte devlet erkânının da hususî teşvikleri ile farklı bölgelerde inşa edilen bu tür ilmî müesseseler, toplanma yeri ve zamanı bakımından imlâ meclislerine daha sistematik bir hüviyet kazandırmıştır. Muhaddislerin yanı sıra halk nezdinde de hüsn-i kabul gören imlâ oturumları; Bağdat, Basra, Dımaşk, Medine, Kazvin, İsfahan, Herat, Merv ve Nişabur gibi çok sayıda bölgede akdedilmiştir. Bununla birlikte düzenlenen toplantılara sayıca geniş kitlelerin iştirak etmesi de hem toplum nezdinde imlâ faaliyetlerine yönelik entelektüel merakı artırmış hem de bölgenin hadis kültürüne zenginlik katmıştır.

Bu bağlamda imlâ meclisleri, âlimlerden siyasetçilere kadar farklı toplum kesimlerini "hadis" ortak paydasında bir araya getirerek sosyal bir dokunun oluşmasını da temin etmiş̧ir. Ayrıca hadislerin yazılı rivayetinde ve muhafazasında önemli bir rol oynayan bu yöntemle, erken dönemlerden itibaren çeşitli bölgelerde akdedilen geniş katılımlı imlâ toplantıları sayesinde hadis edebiyatında kayda değer bir literatür ortaya çıkmıştır. Öyle ki bu oturumlarda değişik tür ve çapta cüz', meclis ve emâlî şeklinde isimlendirilen çok sayıda edebi eser meydana gelmiş; bu faaliyetler neticesinde hadis literatürüne ve hadis kültürüne önemli bir katkı sağlamıştır. 

of Imlā and Its Reflections to Hadith Literature | 147

10. (16.) yüzyıla gelindiğinde ise imlâ faaliyetleri, dönemin ilim ve kültür anlayışındaki değişimin de etkisi ile kitaplara itimadın artması, hadislerin büyük ölçüde müdevven hale gelmesi ve hadis hâfızları ile şevkli talebelerin azalması gibi çeşitli nedenlerle eski önemini kaybetmiştir. Bu çalışmada muhaddislerin yanı sıra âlimlerden siyasetçilere kadar, toplumun hadise ilgi duyan hemen her kesimi üzerinde entelektüel bir merak uyandıran imlâ usûlünün tarihi serencâmı ele alınmış, imlâ faaliyetlerinin hadis kültür tarihine ve literatürüne yansımaları incelenmiştir.

Anahtar Kelimeler: Hadis, Rivayet, Kitâbet, İmlâ, Emâlî.

\section{Giriş}

Hadis tarihinin ilk dönemlerinden itibaren müslümanlar, rivayet malzemelerini sonraki nesillere aktarmak adına büyük bir gayret sarf etmişlerdir. Sahabîlerin âyetlerin yanı sıra hadislerin yazımına da ilgi duyması ve bu doğrultuda bazı sahâbîlerin cüzî miktarda hadis ihtiva eden sahîfeler vücuda getirmeye yönelmeleri, hadise verilen değerin bir göstergesidir. ${ }^{1}$ Öyle ki hadis tarihinin ilk dönemlerinden itibaren bir yandan hadislerin şifâhî nakline önem verildiği ve imkân dâhilinde hafızaya yardımcı olmak maksadıyla yazıya başvurulduğu; ilerleyen süreçte de muhtelif yazı malzemeleri kullanılarak hadislerin yazılı muhafazasına yönelik hassas bir çaba içerisine girildiği anlaşılmaktadır. ${ }^{2}$ Bu doğrultuda teknik detayları bir tarafa konulursa, basit düzeyde ilk imlâ faaliyetlerini Hz. Peygamber (sav) döneminden itibaren başlatmak mümkündür. Nitekim Râmhürmüzî (öl. 360/971) ilk mümlînin Hz. Peygamber (s.a.v), ilk müstemlînin ise ashâb olduğunu belirtmiştir. Bu görüşe göre Hz. Peygamber (s.a.v) birtakım hususları Hz. Ali’ye (öl. 40/661) imlâ ettirmiş, o da bunları bir deri parçasına yazmıştır. ${ }^{3}$ Yine kendisinin vefatından önce gerçekleşen kırtâs hadisesi de $\mathrm{Hz}$. Peygamber'in (s.a.v) ashabına birşeyler yazdırmak istemesine delil

1 Talât Koçyiğit, Hadis Tarihi (Ankara: TDV Yayınları, 2019), 26.

2 Ayrıntı için bk. Muhammed Ebû Zehv, Hadis ve Hadisçiler, çev. Selman Başaran Mehmet Ali Sönmez (İstanbul: Ensar Neşriyat, 2016), 79-83.

3 Ebû Muhammed ibn Hallâd er-Râmhürmüzî, el-Muhaddisü'l-fâsıl beyne'r-râvî ve'l-vâ' thk. Muhammed Accâc el-Hatîb (Beyrut: Dâru'l-fikr, 1984), 601. 
148 I M. TANRIVERDİ / Rivayetlerin Muhafazasına ve Nakline Yönelik Entelektüel Bir İlgi: İmlâ Usûlü ve Hadis Literatürüne Yansımaları

gösterilebilir. ${ }^{4}$ Benzer şekilde Abdullah b. Amr b. el-Âs'ın (öl. 65/685) kendisine yöneltilen bir soru üzerine Hz. Peygamber'den (s.a.v) yazdığ ve sandık içerisinde muhafaza ettiği bir kitap çıkartarak aynı soruya $\mathrm{Hz}$. Peygamber'in (s.a.v) verdiği cevabı aktarmış olması da bu minvalde değerlendirilebilir. ${ }^{5}$

Hz. Peygamber'in (s.a.v) İslam'a davet mektupları, vahiy kâtiplerine yazdırdığı âyetler, anlaşma metinleri, savaşlara iştirak edenlerin listesi, imtiyaznâmeler, emannâmeler, bazı ahit ve nüfus sayımı vesikaları da bu duruma örnek olarak gösterilebilir. ${ }^{6}$ Ancak hem dar çerçeveli hem de şahsi gayretlerle gerçekleştirilen umumî ve resmi olmayan yazım faaliyetlerinden ibaret olan bu hususi durum, hadislerin bizzat Hz. Peygamber (s.a.v) tarafından sistemli ve kapsamlı bir şekilde yazdırıldığı anlamına gelmemektedir. Çünkü bu dönemde, en azından belli bir süre için, hadis yazımının çeşitli gerekçelerle yasaklandığı bilinmektedir. ${ }^{7}$

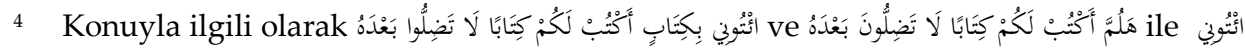

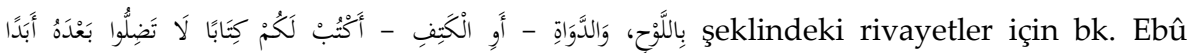
Abdillâh Muhammed b. İsmâîl el-Buhârî, el-Câmi'u's-sahîh, nşr. Muhammed Züheyr b. Nasr (b.y.: Dâru tavki'n-necât, 1422/2001), "İlim", 39 (No: 114), “Cihâd", 175 (No: 3053), “Cizye”, 6 (3168), “Meğâzî”, 83 (4431-2), “Merdâ", 17 (No: 5669), "İ'tisâm”, 26 (No: 7366); Ebü'l-Hüseyn Müslim b. el-Haccâc b. Müslim, el-Câmi'u's-sahîh, thk. Muhammed Fuâd Abdulbâkî (Beyrut: Dâru'l-kütübi'l-'ilmiyye, 1412/1991), "Vasiyyet", 20 (No: 1637); Ebû Abdillâh Ahmed b. Muhammed b. Hanbel, el-Müsned, thk. Şu'ayb el-Arnaût - Âdil Mürşid (Beyrut: Müessesetu'r-risâle, ts.), 3/409 (No: 1935), 5/135 (No: 2990), 5/222 (No: 3111), 5/351 (No: 3336).

50

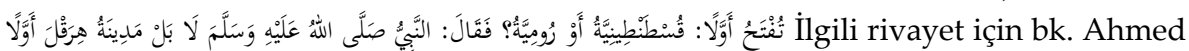
b. Hanbel, el-Müsned, 11/224-225 (No: 6645); Dârimî, “Mukaddime”, 43 (No: 503)

6 Ebû Sa'd Abdülkerîm b. Muhammed es-Sem'ânî, Edebü'l-imlâ ve'l-istimlâ', thk. Max Weisweiller (Beyrut: Dâru'l-kütübi'l-'ilmiyye, 1401/1981), 12; M. Tayyib Okiç, Bazı Hadis Meseleleri Üzerine Tetkikler (İstanbul: Osman Yalçın Matbaası, 1959), 95.

7 İslam'ın bidâyetinde yazının yeterince gelişme göstermemiş olması, yerleşik bir dinî kültürün olmaması, vahiy olan ile olmayanı tefrik edecek bir altyapının her Müslümanda bulunmaması, yeterli düzeyde okuma yazma bilen kişinin olmaması, hâkim geleneğin ezber ve şifâhî usüle dayanması gibi nedenlerin yanı sıra yazılanların Kur'an'la karışma endişesi ile hadis yazımının yasaklandığı anlaşılmaktadır. Bk. Ebû Bekr Ahmed b. Alî el-Bağdâdî, Takyîdü'l-'ilm, thk. Yûsuf el- 

of Imlā and Its Reflections to Hadith Literature | 149

Hadislerin yazılı nakli göz önüne alındığında hadis tarihi, temelde birbirini takip ve takviye eden üç ana aşamada incelenebilir. Bunlardan ilki, "şifahî dönem" olup bu dönemde bilinçli ve sistemli bir hadis yazımından söz etmek mümkün değildir. Hicrî birinci asrın ayırt edici özelliği olan bu nakil biçiminde rivayetler genellikle şifahî olarak alınıp yine aynı yöntemle nakledilmekte idi. Ferdî olarak az sayıda hadis yazanlara rastlansa da bu kimselerin amacı, derli-toplu yazılı bir metin elde etmek ve bunu sonraki nesle bırakmak değildi. Bunlar sadece şifahî rivayeti kolaylaştırmak veya unuttuklarında hatırlamak amacıyla "müzekkirat" kabilinden sistemsiz notlardan ibaret idi. Bu dönemden sonra hadis naklinde yazı malzemesinin bilinçli ve etkin bir şekilde kullanıldığı bir zaman dilimine girilmiştir. Yaklaşık olarak 2. (8.) yüzyıldan 4. (10.) yüzyılın sonlarına kadar uzanan "sistematik rivayet dönemi" nde yazı, hadis rivayetinde belirleyici unsur olmuş; rivayetlerin muhafazasında ve naklinde önemli bir rol oynamıştır. Bundan sonraki süreç ise 5. (11.) yüzyıldan 14. (20.) yüzyıla kadar süren "nakil dönemi" şeklinde nitelendirilebilir. Çünkü bu aşamada hadis kitaplarının nakli

Iş (by.: Dâru ihyâi sünneti'n-nebeviyye, ts.), 49; Muhammed Accâc el-Hatîb, es-Sünne kable't-tedvin (Kahire: Mektebetü Vehbe, 1988), 303, 310. Söz konusu problemlerin aşılmasıyla birlikte yazıya âşinâ bazı sahabîlere verilen özel izin, zamanla genele yayılmış ve sahabenin hadis yazımının önünde herhangi bir engel kalmamıştır. Ebû Ömer Cemâlüddîn Yûsuf b. Abdillâh b. Abdilberr, Câmi'u beyâni'l-ilm ve fadlih, thk. Ebü'l-Eşbâl ez-Züheyrî (Kahire: Dâru'l-harameyn, ts.), 1/298-299. Tabi'ûn dönemine gelindiğinde yazım hususunda birtakım bürokratik kanalların da devreye girmesiyle hadis yazımı rağbet görmüştür. Ancak yine de bu dönemde de hadis yazımına karşı bir tavrın varlığını koruduğu görülmektedir. Nitekim İbn Şihâb ez-Zührî (öl. 124/741) "Yöneticiler bizi zorlayana kadar, hadis yazımına hoş bakmazdık. Fakat daha sonra hiçbir Müslümanı alıkoyamayacağımı anladım." Bk. Ebû Abdillâh Şemsüddîn Muhammed ez-Zehebî, Siyeru a'lâmi'n-nübelâ', thk. Şuayb el-Arnavûd (Beyrut: Müessesetü'r-risâle, 1985), 5/334. Ne var ki özellikle uydurma rivayetlerin çoğalmasıyla sahih rivayet toplama isteği, sahabenin vefatı, rihlelerin başlaması ve yöneticilerin yazımı teşvik eden tutumu, bu yönde müspet bir atmosfer oluşturmuştur. Bu bağlamda söz konusu atmosferin imlâ meclislerinin çoğalıp yaygınlaşmasını olumlu yönde etkilediği ve bu meclislerdeki hadis yazım faaliyetlerini de hızlandırdığı söylenebilir. 
150 । M. TANRIVERDİ / Rivayetlerin Muhafazasına ve Nakline Yönelik Entelektüel Bir İlgi:

İmlâ Usûlü ve Hadis Literatürüne Yansımaları

esas alınmış ve hadis öğrenim ve öğretim faaliyetleri merkezî ve kurumsal hale getirilmiştir. ${ }^{8}$

Şifâhî rivayet döneminin ardından hicrî ikinci asrın başlarından itibaren artan hadis yazım faaliyetleri sonucu ortaya çıkan metinler, bazı problemleri de beraberinde getirmiştir. Bunlardan ilki bu ilim konusunda ehil olmayan kimselerin hadis rivayetine yönelerek hadisleri hocadan almak yerine sahifelerden almayı tercih etmeleridir. $\mathrm{Bu}$ dönemde Arap yazısının henüz yeterince gelişmemiş olması da söz konusu rivayetlerde tashîf ve tahrîf endişesini gündeme getirmiştir. ${ }^{9}$

Muhaddisler bu problemi çözmek adına bazı tedbirler geliştirmişlerdir. Buna göre doğrudan hadis sahifelerinden alınarak rivayet edilen metinlerde çeşitli hatalar olabileceğine dikkat çekilmiş ve hadisleri sadece hocadan alma geleneğinin önemi vurgulanmıştır. ${ }^{10} \mathrm{Bu}$ doğrultuda bir kontrol mekanizması olarak hocanın onayını öngören semâ' ve kıraat metotları geliştirilmiş; hadis almada sahifeler yerine doğrudan doğruya hoca esas kabul edilmiştir. Bu tedbirlere paralel olarak rivayet edilecek hadislerde kullanılması öngörülen hususi edâ lafızları belirlenmiştir. Yine semâ' ve kıraat meclislerinde rivayetler üzerinden müzakereler gerçekleştirilerek hataların önüne geçilmesi hedeflenmiştir.

Tüm bu gelişmelerin tabii seyri içerisinde rivayet malzemesini muhafaza etme ve sonraki nesillere doğru aktarma çabası, imlâ adı

8 Ahmet Yücel, Hadis Tarihi (İstanbul: MÜ İlahiyat Fakültesi Vakfı Yayınları, 2011), 2224, 40-42.

9 Nitekim Huneys'i Hubeyş yapma hansâ' kelimesini haysâ' şekline dönüştürme yahut Übey'i Ebî yapma gibi hatalar rivayete konu olan malzemenin aslından kopmasına neden olmuştur. Bk. Ebû Bekr Ahmed b. Alî el-Bağdâdî, el-Kifâye fî̀ ilmi'rrivâye, thk. Ebû Abdillâh es-Sûrkî - İbrâhîm Hamdî el-Medenî (Medine: elMektebetü'1-'ilmiyye, 1357), 248-249; Ebû Amr Takıyyüddîn Osmân b. Salâhiddîn eşŞehrezûrî, Ulûmu'l-hadîs, thk. Nureddin Itır (Beyrut: Dâru'l-fikr, 1406/1986), 279-280. Tashîf örnekleri için bk. Ümmügülsüm Yeşil, “Tashîf ve Tahrîf Üzerine Bazı Mülâhazalar", Hadis Tetkikleri Dergisi 18/1 (Temmuz 2020), 147-156.

10 Nitekim hadisi yazılı metinlerden rivayet eden sahafîlerden almama uyarısı yapılmıştır. Bk. Râmhürmüzî, el-Muhaddisü'l-fâsıl, 211; Ebu Muhammed Abdurrahmân b. Ebî Hâtim, el-Cerh ve't-ta'dîl (Beyrut: Dâru'l-kütübi'l-'ilmiyye, 1372/1953), 2/31, 3/402; Yücel, Hadis Tarihi, 44. 

of Imlā and Its Reflections to Hadith Literature | 151

verilen özel bir yöntemin gelişmesini temin etmiştir. Hadislerin yazılı naklinde önemli bir fonksiyon icra eden bu yöntem sayesinde rivayetler, bir yandan tashîf ve tahrîf gibi dış etkenlerden korunmuş olmakta diğer yandan da hoca-talebe mülâkatını zorunlu kılması bakımından güvenilir bir kontrol mekanizmasına imkan sağlamış olmaktadır.

\section{1. İmlâ Usûlü}

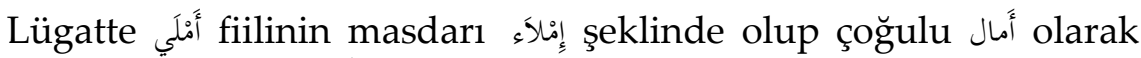

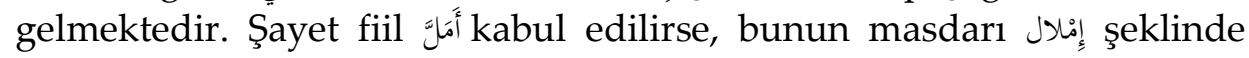
gelir. Lügat manası itibarıla imlâ; yazdırmak ve dikte etmek anlamına geldiği gibi mühlet vermek ve süre tanımak anlamına da gelmektedir. ${ }^{11}$ Kur'an-1 Kerîm'de her iki duruma örnek olarak da âyet bulunmaktadır.

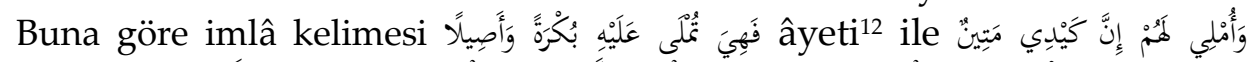

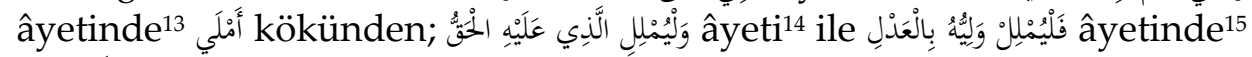

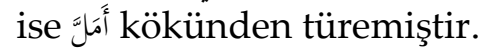

Istılahta ise imlâ, kelimenin yazdırma anlamına atfen daha ziyade “bir kimsenin etrafındakilere ezberinden veya kitaptan bir şey yazdırması" 16 şeklinde kullanılmaktadır. Bu yöntem sadece hadis ilmine mahsus olmayıp aynı zamanda başta Arap dili, tefsir ve usûl-i fıkıh olmak üzere birçok sahada da kullanılmıştır. Örneğin Ebû Bekir Muhammed b. el-Kâsım el-Enbârî'nin (öl. 328/940) dil, nahiv, lugat, şiir ve edebiyatın yanı sıra tefsir, hadis ve ahbâra dair çeşitli notlarından oluşan el-Emâlî (el-Mecâlis, el-Mücâlesât) adlı eseri bu bağlamda zikredilebilir. Benzer şekilde Ebû Alî el-Kâlî (öl. 356/967) tarafından

11 Ebû Nasr İsmâîl b. Hammâd el-Cevherî, es-Sthâh tâcü'l-lüga ve sthâhı'l-'Arabiyye, thk. Ahmed Abdulgafûr Attâr (Beyrut: Dâru'l-'ilm li'l-melâyîn, 1990), "mle", 4/2497; Ebü'l-Fazl Cemâlüddîn Muhammed İbn Manzûr, Lisânü'l-'Arab (Beyrut: Dâru Sadr, ts.), "mll", 11/631, "mle", 15/291; Ebü'l-Feyz Muhammed el-Murtazâ ez-Zebîdî, Tâcü'l-'arûs min cevâhiri'l-kâmûs, thk. Komisyon (b.y.: Dâru'l-hidâye, ts.), "mll", 30/424, "mle", 39/555. Kelimenin lügat anlamiyla ilgili tahlil için bk. Üzeyir Tuna, "Arap Dili ve Edebiyatıyla İlgili Emâlîler", Bayburt Üniversitesi İlahiyat Fakültesi Dergisi 5/9 (Haziran 2019), 118-121.

12 “... Bunlar sabah akşam ona yazdırılmaktadır." el-Furkan, 25/5.

13 “Onlara süre tanır, mühlet veririm. Fakat benim tuzağım şiddetlidir." el-A'râf, 7/183.

14 “... Üzerinde hak olan (borçlu) da yazdırsın ..." el-Bakara, 2/282.

15 “... O zaman da velisi adaletle yazdırsın ..." el-Bakara, 2/282.

16 Abdullah Aydınlı, "İmlâ", Türkiye Diyanet Vakfı İslam Ansiklopedisi (İstanbul: TDV Yayınları, 2000), 22/225. 
152 | M. TANRIVERDİ / Rivayetlerin Muhafazasına ve Nakline Yönelik Entelektüel Bir İlgi: İmlâ Usûlü ve Hadis Literatürüne Yansımaları

Endülüs'te 330/941 ile 350/961 yılları arasında imlâ ettirilen ve dönemin edebî yönüne 1şık tutan eseri el-Emâlî bu bağlamda zikredilebilir. ${ }^{17}$

Hadis ilmi açısından imlâ kavramı; muhaddisin çevresinde yer alan veya ondan hadis dinlemek üzere bir araya gelmiş kimselere hadis yazdırması demektir. ${ }^{18}$ Yani imlâ; hocanın, rivayet hakkını elde ettiği hadisleri bir veya genellikle daha fazla talebeye hifzindan yahut kitaptan yazdırması anlamına gelir ve bu yöntem hadis alma yollarının en üstünü ${ }^{19}$ olarak kabul edilen semâ' metodu $^{20}$ içerisinde mütalaa edilir. ${ }^{21}$ Çünkü diğer hadis alma yollarıyla mukayese edildiğinde imlâ metodunda hem hoca hem talebe faal bir konumda bulunmaktadır. Hadis tahammülünde hoca ve talebeye yüklediği aktif rol bakımından bu yöntem, hadis ilminde muteber bir usûl olarak kabul edilmiştir. ${ }^{22}$

\section{2. İmlâ Usûlünün Tarihçesi}

İmlâ faaliyetlerine yönelik ilk girişimler Hz. Peygamber (s.a.v) dönemine kadar geriye götürülebilirse de söz konusu "yazdırma" faaliyetlerini sistematik olmaktan uzak, mevcut ihtiyaçları karşılamaya

17 Ebû Alî el-Kâlî bu eserin yaklaşık üçte birini teşkil eden yedi yüz kadar rivayeti hocası İbn Düreyd'in Emâlî'sinden nakletmektedir. Bk. Muhammed Abdülcevâd elAsmaî, "Mukaddime", el-Emâlî, mlf. Ebû Alî İsmâîl b. el-Kâsım el-Kâlî (Kahire: Dâru'l-kütübi'l-'ilmiyye, 1970), 1/1-18; Ebû Gays Muhammed Hayrüddîn ez-Ziriklî, el-A'lâm: Kâmûsü terâcim (Beyrut: Dâru'l-'ilm li'l-melâyîn, 2002), "Ebû Alî el-Kâlî", 1/321-322. Eserle ilgili çalışma için bk. Hamza Özaslan, Ebû Alî el-Kâlî ve Kitâbü'lEmâlı̂ (İstanbul: İstanbul Üniversitesi, Sosyal Bilimler Enstitüsü, Yüksek Lisans Tezi, 1996).

18 Ebü'l-Fazl Celâlüddîn Abdurrahmân es-Suyûtî, Tedrîbu'r-râvî fî şerh-i takrîbi'n-Nevevî, thk. Muhammed el-Firyâbî (Beyrut: Mektebetü'l-kevser, 1410), 2/574.

19 Ebû Bekr Ahmed b. Alî el-Bağdâdî, el-Câmi' li ahlâki'r-râvî ve âdâbi's-sâmi', thk. Mahmûd Tahhân (Riyâd: Mektebetü'l-ma'ârif, 1983), 2/55; Ebü'l-Hayr Şemsüddîn Muhammed b. Abdirrahmân es-Sehâvî, Fethu'l-muğ̆̂̀s bi-şerhi Elfiyyeti'l-hadîs, thk. Alî Hüseyin Alî (Mısır: Mektebetü's-sünne, 1424/2003), 2/157.

20 Bk. Hatîb el-Bağdâdî, el-Kifâye fì ilmi'r-rivâye, 271; Suyûtî, Tedrîbu'r-râvî, 1/443.

21 Ebü'l-Fazl Kâdî İyâz b. Mûsâ el-Yahsubî, el-İlmâ' ilâ ma'rifeti usûli'r-rivâye ve takyîdi'ssemâ', thk. Seyyid Ahmed Sakr (Kahire: Dâru't-türâs, 1970), 69; Nureddin Itr, Menhecü'n-nakd fî ulûmi'l-hadîs (Dımaşk: Dâru'l-fikr, 1399/1979), 214; Abdullah Aydınlı, Hadis Istılahları Sözlüğ̈̈̈ (İstanbul: MÜ İlahiyat Fakültesi Vakfı Yayınları, 2009), "İmlâ", 136; Selman Başaran - Mehmet Ali Sönmez, Hadis Tarihi ve Usûlü (b.y.: Esra Fakülte Kitabevi, 1993), 72.

22 Sehâvî, Fethu'l-muğ̆̂s, 2/157. 

of Imlā and Its Reflections to Hadith Literature | 153

dönük çabalar olarak mütalaa etmek gerekir. ${ }^{23}$ Şifâhî ve yazılı rivayetin iç içe yürüdüğ̈̈ erken dönemde kesin bir başlangıç tarihine işaret etmek mümkün olmasa da hadis tarihi özelinde ilk imlâ faaliyetlerinin 2. (8.) yüzyıldan itibaren görülmeye başlandığı, bu yüzyılın ortalarına gelindiğinde sistemli ve kapsamlı hadis yazdırma faaliyetlerinin yaygınlaştığ1 söylenebilir. Nitekim Hatîb el-Bağdâdî (öl. 463/1071) sahabeden Vâsıle b. el-Eskâ' el-Leysî'nin (öl. 85/704) hadis derslerinde

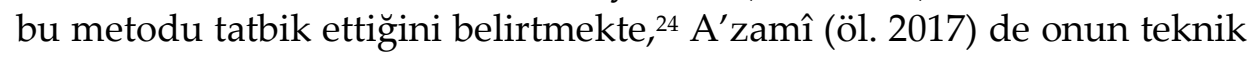
anlamda imlâ için toplantı akdeden ilk kimse olduğunu kaydetmektedir. ${ }^{25} \mathrm{Bu}$ bağlamda söz konusu hadis yazdırma ameliyesi, rivayet malzemesini muhafaza ve nakil anlaminda hadis tarihindeki en erken teşebbüs olarak değerlendirilebilir.

Hadis yazdırma maksadıyla düzenlenen meclislere imlâ meclisi adı verilir. $\mathrm{Bu}$ meclisler, başlangıçta birtakım teâmüller üzerinden varlığını sürdürmüş, zamanla yaygınlaşarak kendi hususi kurallarını geliştirmiş ve düzenli toplantılar halini almıştır. Sahabe döneminde Vâsıle b. el-Eskâ' ile başlayan imlâ meclislerinin tabi'ûn dönemine gelindiğinde muhaddisler nezdinde büyük rağbet gördüğü anlaşılmaktadır.

Öyle ki İbn Şihâb ez-Zührî (öl. 124/742), Husayn b. Abdirrahmân (öl. 136/753), Eş’as b. Abdilmelik (öl. 142/759), Leys b. Ebî Süleym (öl. 148/765) ve A’meş (öl. 148/765) gibi birçok muhaddis bu metodu tatbik etmiştir. ${ }^{26}$ Kimi muhaddislerin sadece imlâ yoluyla hadis almayı kriter haline getirmesi de bu meclislerin önemini artırmıştır. Öyle ki Ebû Hayseme Züheyr b. Muâviye el-Kûfî (öl. 173/789) hadis almada sadece imlâ usulünü benimsemiştir. ${ }^{27}$ Ebû Osman Affân b. Müslim el-Ensârî (öl. 220/835) ise Hammâd b. Seleme'ye (öl. 167/784) imlâ dışında hadis

23 Okiç, Hadis Meseleleri, 95.

24 Hatîb el-Bağdâdî, el-Câmi', 2/55.

25 Muhammed Mustafa A'zamî, Studies in Hadith Methodology and Literature (Riyad: y.y., 1977), 18.

26 Râmhürmüzî, Muhaddisü'l-fâsıl, 605; A'zamî, Studies, 18.

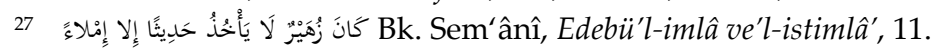


154 | M. TANRIVERDİ / Rivayetlerin Muhafazasına ve Nakline Yönelik Entelektüel Bir İlgi: İmlâ Usûlü ve Hadis Literatürüne Yansımaları

yazmadıklarını söylemiştir. ${ }^{28}$ Yine İbn Cüreyc (öl. 150/767) Basra'ya geldiğinde Ebü'l-Müsennâ Muâz b. Muâz et-Teymî (öl. 196/811) ona imlâ usulü dışında hadis almadıklarını söyleyerek kendisinden imlâda bulunmasını talep etmiştir. ${ }^{29}$ Yine Ebû Bekir İbn Ebî Şeybe'nin (öl. 235/850) "Yirmi bin hadisi imlâ ile yazmayan, kendisini ilim (hadis) sahibi saymasın" 30 şeklindeki kaydı, bu metodun hadis naklinde yaygın ve muteber bir usûl olduğuna işaret etmektedir. Bu durumun tabiî bir sonucu olarak imlâ meclisleri, okuma-yazma bilenlerin artması ve yazının ilerleme kaydetmesi ile entelektüel bir ilgiyle takip edilmiştir. ${ }^{31}$

3. (9.) yüzyıl itibariyle yaygınlaşan hadis imlâ faaliyetleri, oldukça kalabalık grupların ilgisine mazhar olmuştur. Öyle ki Buhârî́nin (öl. 256/870) şeyhlerinden Âsım b. Ali b. Âsım'ın (öl. 221/836) Rusâfe mescidinin yanındaki geniş hurmalık alanda akdettiği imlâ oturumu büyük bir rağbet görmüştü. Kaynakların aktardığına göre insanlar geniş bir satha yayılmış, Âsım ise yüksek bir yere oturmuştu. Cemaat o kadar fazlaydı ki insanlar onu duyamadıkları için hadislerin sürekli tekrar edilmesini istiyorlardı. Nitekim o, Leys b. Sa'd (öl. 175/791) rivayetini tam on dört kez tekrarladı. Buna rağmen uzaktaki gruplardan hala işitmeyenler vardı. Kimisi duyduklarını daha rahat yazabilmek için hurma ağaçlarına çıkmıştı. Dönemin halifesi Mu'tasım'ın (öl. 227/842) da

28 Bk. Ebû Abdillâh Ahmed b. Muhammed b. Hanbel, Kitâbü'l-'ilel ve ma'rifeti'r-ricâl, thk. Vasiyullah b. Muhammed Abbâs (Riyad: Dâru'1-hânî, 1422/2001), 2/350.

29 Bk. Zehebî, Siyeru a'lâmi'n-nübelâ', 10/245.

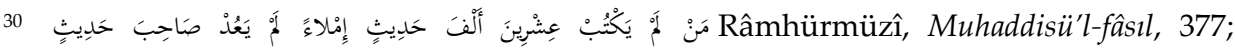
Sem'ânî, Edebü'l-İmlâ, 11; Suyûtî, Tedrîbu'r-râvî, 1/34.

31 Zira erken devirlerde rivâyet malzemesinin tamamı yazılı kayda geçirilmemişti. Bu sebeple âlî isnâd elde etmek ve sika râvilerden nakilde bulunmak isteyen hadis meraklıları, imlâ toplantılarına rağbet göstermişlerdir. Bu itibarla özellikle Yezîd b. Hârûn (öl. 206/821), Âsım b. Alî el-Vâsitî (öl. 221/836), Amr b. Merzûk el-Bâhilî (öl. 224/839) ve Buhârî (öl. 256/870) gibi meşhur muhaddislerin akdettikleri imlâ meclislerine katılım oldukça yoğundu. Bu tür muhaddislerin meclislerine özel önem verilir, katılım için günler öncesinden seyahatlere çıkılır ve imlâ yapılacak meclis vaktinden önce doldurulurdu. Bk. Hatîb el-Bağdâdî, el-Câmi', 2/54-55, 138; Sem'ânî, Edebü'l-İmlâ, 17, 96, 113. 

of Imlā and Its Reflections to Hadith Literature | 155

iştirak ettiği bu imlâ meclisinde yüz yirmi bin insan bulunuyordu. ${ }^{32}$ Benzer şekilde Ebû Müslim el-Keccî (öl. 292/904) Gassân meydanında yaklaşık kırk bin kişilik yoğun bir kalabalığa hadis imlâsında bulunmuştur. ${ }^{33}$ Hazır bulunanlar kalabalık sebebiyle duyduklarını ancak ayakta yazabilmişlerdir. ${ }^{34}$ Yine Sâlih b. Muhammed el-Bağdâdî, (öl. 293/906) Bağdat'ta bulunduğu sırada hadis imlâ meclisi düzenleyen Buhârî’ye (öl. 256/870) müstemlîlik yaptı̆̆ını ve yirmi binden fazla topluluğun kendilerini dinlediğini belirmiştir. ${ }^{35}$

Burada katılımcılardan uzaktakilerin duyamaması ya da eksik ve hatalı duyduğu şeyleri yazma ihtimalinin bulunması, imlâ yoluyla oluşturulan sahife ve cüzlerin, hatta bu yöntemin güvenilirliğini olumsuz etkilediği düşünülebilir. Ancak bu tür toplantılarda katılımcıların tamamının hadis yazmak için gelmediği, her birinin yazmayı bilmediği ve içlerinden bir kısmının "nezzâre" adı verilen gözlemcilerden oluştuğu anlaşılmaktadır. ${ }^{36}$ Ayrıca hadis yazan talebelerin imlâ oturumu sona erdikten sonra nüshalarını karşılaştırmaları, imlâ sırasında bazı talebelerin yazım konusunda ehil kimselerden yardım almaları, ortaya çıkan nüshaların kopya işlemi için "varrâk" adı verilen ehliyetli meslek erbabına müracaat edilmesi ve nihayetinde mevcut nüshaların hadis yazdıran hocaya tashih ettirilmesi şeklinde yürütülen teâmüller, bu tür toplantıların hadis almada güvenilir bir imkân sunduğunu göstermektedir.

Kaynaklar devlet erkânının da bu tür meclislere yoğun ilgi gösterdiğini kaydetmektedir. Nitekim Emevî halifesi Hişâm b. Abdilmelik (öl. 125/743), hadis imlâsına önem vermiş ve kâtibi vasıtasıyla çocuklarından bazılarına dört yüz kadar hadis imlâsında bulunmuştur. ${ }^{37}$ Yine Mansûr, Hârûnürreşîd ve Me'mûn gibi Abbasî

32 Bk. Ebû Bekr Ahmed b. Alî el-Bağdâdî, Târîhu Bă̆gad, thk. Mustafa Abdülkâdir 'Atâ (Beyrut: Dâru'l-kütübi'l-'ilmiyye, 1417), 12/242; Sem'ânî, Edebü'l-imlâ ve'l-istimlâ', 1617; Suyûtî, Tedrîbu'r-râvî̀, 2/575.

33 Hatîb el-Bağdâdî, Târîhu Bă̆dad, 6/120.

34 Hatîb el-Bağdâdî, el-Câmi', 2/53; Sem'ânî, Edebü'l-imlâ ve'l-istimlâ', 9; Suyûtî, Tedrîbu'rrâvî, 2/575.

35 Hatîb el-Bağdâdî, el-Câmi', 2/53; Sem'ânî, Edebü'l-imlâ ve'l-istimlâ', 17.

36 Aydınlı, "Nezzare", 246.

37 Kâdî İyâz, el-İlma', 243-244. 
156 | M. TANRIVERDİ / Rivayetlerin Muhafazasına ve Nakline Yönelik Entelektüel Bir İlgi: İmlâ Usûlü ve Hadis Literatürüne Yansımaları

halifeleri de imlâ meclislerine iştirak etmişlerdir. ${ }^{38}$ Selçuklu veziri Nizâmülmülk (öl. 485/1092) ise bizzat kendisi hadis imlâsında bulunmuş, Bağdat'ta Nizâmiye Medresesi ve Câmi'u'l-Mehdî'de imlâ meclisleri düzenlemiştir. ${ }^{39}$ Yöneticilerin imlâ toplantılarına önem vererek bu tür ortamlara bizzat katılmaları ${ }^{40}$ toplum nezdinde bir teşvik unsuru olmuş ve bu meclislerin önemini daha da artırmıştır.

İmlâ metodu, hadis naklinde 2. (8.) yüzyılın ortalarından itibaren düzenli olarak uygulanmaya başlamış ve 10. (16.) yüzyıl itibariyle önemini kaybetmiştir. Bunda hadis hâfızlarının azalması, hocalardan ziyade kitaplara itimadın artması, hadislerin isnâdının uzaması, rivâyet malzemesinin büyük oranda müdevven hale gelmiş olması, imlâ talebinde bulunan şevkli öğrencilerin azalması gibi çeşitli faktörlerin ${ }^{41}$ yanı sıra dönemin ilim ve kültür anlayışındaki değişimin de etkili olduğu söylenebilir.

İmlâ usûlü, aynı zamanda uygulandığı dönemin hadis ilmine bakış açısını da yansıtmıştır. Nitekim 4. (10.) yüzyıla kadar konu bütünlügüne bakılmaksızın doğrudan doğruya imlâ edilen tüm hadislerin olduğu gibi nakledilmesi amaçlanmıştır. $\mathrm{Bu}$ süreçte gerçekleştirilen imlâ toplantılarında amaç, dönemin hakim hadis anlayışı gereği hadisleri senedleriyle beraber eksiksiz olarak sonraki nesle aktarmak, isnâdta yer alan râvilerin cerh ve ta'dîlini yapmak, metinlerdeki garip lafızları izah etmekti. ${ }^{42}$

5. (11.) asra gelindiğinde imlâ meclisleri nispeten daha farklı bir amaçla düzenlenmeye başlamış ve bu dönemde başta fıkhî içerikli hadisler olmak üzere özellikle amellerin faziletlerine dair rivâyetler imlâ toplantılarının ana gündemini oluşturmaya başlamıştır. Burada söz

38 Sem'ânî, Edebü'l-imlâ ve'l-istimlâ', 19-21; Ordusunun geçiş güzergâhında Yezîd b. Hârûn'un imlâ meclisine tanık olan Halife Me'mûn "Gerçek sultan budur" demiştir. Bk. Ebû Bekr Ahmed b. Alî el-Bağdâdî, Şerefu ashâbi'l-hadîs, thk. M. Said Hatiboğlu (Ankara: AÜ İlahiyat Fakültesi Yayınları, 1972), 100.

39 M. Yaşar Kandemir, "Emâlî”, Türkiye Diyanet Vakfı İslam Ansiklopedisi (İstanbul: TDV Yayınları, 1995), 11/70-71.

40 Hatîb el-Bağdâdî, el-Câmi', 2/55.

41 Ebû Abdillâh Muhammed b. Ca'fer el-Kettânî, Hadis Literatürü, çev. Yusuf Özbek (İstanbul: İz Yayınları, 1994), 339.

42 Kettânî, Hadis Literatürü, 339. 
konusu içeriğe sahip hadislerin imlâsı ile toplumun ahlakî yapısına katkı sunmanın ve insanlarda amellerini düzeltme konusunda bir farkındalık oluşturmanın amaçlandığı anlaşılmaktadır. Hadis şerhçiliğinin yaygınlaştı̆̆ dönemlerde ise hakim anlayışına bağlı olarak hadislerin metninden daha çok şerhi imlâ konusu olmuştur.

\section{3. İmlânın Mahiyeti ve İlgili Terimler}

Hadis imlâsı, hoca ile talebe arasında rivayete konu olan hadislerin yazdırılmasına dayanan bir nakil faaliyetidir. Burada hadis yazdıran hocaya mümlî, hadis yazan talebeye ise müstemlî veya kâtip denir. ${ }^{43}$ Kâtip, imlâ meclislerinde hocadan hadis yazan talebe manasina geldiği gibi daha ziyade hadis yazım işini meslek haline getiren ve bu işi bir muhaddisin emrinde ücret mukabilinde yapan kimse manasına gelir. Zira imlâ sisteminin revaçta olduğu dönemlerde müstemlîlik, güvenilir kimselerin icrâ ettiği saygın bir meslek olarak yaygınlaşmıştı. ${ }^{44}$ Tüm talebeler aynı düzeyde hızlı yazamadıklarından bazen hadislerin imlâsı için süratli yazan bir kimse seçilir ve diğer talebeler yazım aşamasında hata yapmaması için etrafına toplanıp onu takip ederlerdi. İmlâ oturumu sona erdiğinde ortaya çıkan emâlî nüshası ya ödünç alınır yahut kopya işlemi için kısa bir süreliğine temlik edilirdi. Bu durum edebî çevrelerde kitap ticaretine yönelik "varrâk" adı verilen bir meslek erbabının doğmasını temin etmiştir. ${ }^{45}$ Benzer şekilde söz konusu nüshaların kopyalandıktan sonra tashîh edilmesi gerekliliği gündeme geldiğinden mümlîler, kopyalanan emâlî nüshalarının mutlak surette aslı ile karşılaştırılmasını ve şeyhin nezaretinde gözden geçirilmesini talep etmişlerdir. Nitekim 'Urve, oğlu Hişâm'a kopya ettiği nüshayı revize ettirip ettirmediğini sormuştur. Aldığı olumsuz cevap üzerine ‘Urve "Esasen içine düştügün bu durum, senin onu hiç yazmadığın anlamina geliyor." demiştir.46

Şeyhten ona ait hadisleri yazdırmasını talep etmeye ise istimlâ adı verilir. Bu talep şeyhten imlâ meclisi akdetmesi yönünde şifâhî bir müracaat şeklinde olabileceği gibi şeyhin muayyen zamanlarda

43 İsmail Lütfi Çakan, Hadis Usûlü (İstanbul: MÜ İlahiyat Fakültesi Vakfı Yayınları, 2010), 52.

44 Okiç, Hadis Meseleleri, 97.

45 A'zamî, Studies, 18.

46 A'zamî, Studies, 19. 
158 I M. TANRIVERDİ / Rivayetlerin Muhafazasına ve Nakline Yönelik Entelektüel Bir İlgi:

İmlâ Usûlü ve Hadis Literatürüne Yansımaları

düzenlediği imlâ meclislerinde hazır bulunmak şeklinde de olabilir. Geniş katılımın sağlandığı imlâ toplantılarında şeyhin sözünü cemaate nakleden görevlilere müstemlî adı verilir. ${ }^{47}$ Mübelliğ olarak da nitelenen bu kimselerin görevi, hadis yazan telebelere şeyhin sözlerini yüksek sesle tekrar etmektir. ${ }^{48}$

İmlâ yönteminin uygulandığı ilk zamanlarda daha az katılımlı meclisler düzenlendiğinden şeyhin okuduğu hadislerin tekrarına ihtiyaç duyulmamıştır. Fakat bu durum zamanla değişmiş ve imlâ meclislerinde okunan hadislerin tekrar edilmesi gerekliliği ortaya çıkmıştır. Bu tür toplantılarda şeyhin sesinin hazır bulunanlara ulaştırılmasında tek müstemlî yetersiz kalmıştır. Bu nedenle meclisin çeşitli noktalarına yerleştirilen çok sayıda müstemlî, hadislerin cemaate duyurulmasında görev almıştır.

Öyle ki, İsmâil b. Abbâd'ın (öl. 385/995) imlâ meclisinde altı, Ebû Müslim el-Keccî'nin (öl. 292/904) meclisinde yedi, Ebû Abdillâh İbn Vâre'nin (öl. 270/884) meclisinde ise yirmi müstemlî hazır bulunmuştur. ${ }^{49}$ Kaydedilen en fazla müstemlî sayısı ise, Firyâbî'nin (öl. 302/914) yaklaşık otuz bin kişilik cemaate Bağdat'ta gerçekleştirdiği imlâ meclisinde görülmüştür. Bu toplantıda Firyâbî'nin naklettiği hadisleri hazır bulunanlara nakletmek için üç yüz on altı müstemlî görev yapmıştır. ${ }^{50}$ İmlâ meclislerine katıldıkları halde hadis yazımında bulunmayıp sadece imlâ faaliyetini gözlemleyen ilgili kimselere ise nezzâre adı verilir. ${ }^{51}$

Görüldügü gibi imlâ faaliyetlerinin hem hadis uleması hem de düzenlenen oturumlara iştirak eden halk düzeyinde entelektüel bir yönünün bulunduğu anlaşılmaktadır. İmlâ meclislerine katılmayı önemli bir vazife olarak gören insanlar, bir muhaddisin hangi gün

47 Talat Koçyiğit, Hadis Istılahları (Ankara: AÜ İlahiyat Fakültesi Yayınları, 1980), 333; Suyûtî, Tedrîbu'r-râvî, 2/576; Başaran - Sönmez, Hadis Tarihi ve Usûlü, 72.

48 Suyûtî, Tedrîbu'r-râvî, 2/576. Ayrıca bk. A'zamî, Studies, 18.

49 Sem'ânî, Edebü'l-imlâ ve'l-istimlâ', 96-97; Suyûtî, Tedrîbu'r-râvî, 2/575.

50 Sem'ânî, Edebü'l-imlâ ve'l-istimlâ', 18; Zehebî, Tezkiratü'l-huffâz, 2/693.

51 Aydınlı, "Nezzare”, 246. 

of Imlā and Its Reflections to Hadith Literature | 159

nerede imlâ meclisi akdedeceğini takip etmişler ve bu oturumlar için günler öncesinden hazırlık yapmışlardır. ${ }^{52}$

Hadislerin müzakere edilip yazdırıldı̆̆ı mekânlara meclisü'l-ilm veya meclisü'l-imlâ adı verilmiştir. Bu mekanların başında mescitler gelmektedir. Hz. Peygamber'den (s.a.v) tevârüs eden bir gelenekle mescitler, uzun süre eğitim-öğretim faaliyetlerinin ana merkezi olmuşlardır. Bu manada Kur'an ve Sünnet başta olmak üzere dinî tedrisatı merkeze alan ve bu ilimleri doğru anlamaya yardımcı olmak üzere Arap şiiri, dil ve edebiyat gibi diğer ilimlerin okutulduğu mekânlar olarak mescitler önemli görevler icra etmişlerdir. ${ }^{53} \mathrm{Bu}$ doğrultuda hadis yazdırma faaliyetleri de büyük oranda mescitlerde yürütülmüştür.

Haftalık düzenlenen imlâ meclisleri için çoğunlukla Cuma namazı kılınan büyük camiler tercih edilmiştir. ${ }^{4}$ Mesela Ebû Bekr b. Ebî Şeybe (öl. 235/849) ve Asım b. Ali el-Vâsıtî (öl. 221/836) Bağdat'taki Rusâfe Mescidi'nde, 55 Ebu'l-Hüseyin Ali b. Hamza Basra Câmii'nde, Velîd b. Utbe ed-Dimeşkî (öl. 240/854) Şamdaki Bâbü'l-Câbiye Mescidi'nde, ${ }^{56}$ Ebû Bekr eş-Şâfîî (öl. 354/965) ise Medine' de Mescid-i Nebî' de ${ }^{57}$ imlâda bulunmuştur. Bunların dışında Bağdat'ta Kasr Câmî̂ ve Mescidü'1Meydan, Basra'da Ebu'l-Esved ed-Düelî Mescidi ile Herat, İsfahan, Kazvin, Merv ve Nişabur câmiîlerinde geniş katılımlı hadis imlâ meclisleri düzenlenmiştir. ${ }^{58}$

Câmiler dışında nadiren de olsa mümlî, kendi evinde nispeten daha az katılımlı imlâ meclisi gerçekleştirmiştir. Şayet hoca, evinden çıkamayacak kadar hasta veya yaşlı ise, ziyarette bulunan talebe ve misafirlerinin isteği üzerine teberrüken küçük çaplı bir imlâ meclisi

52 Öyle ki Ca'fer b. Dürüsteveyh, Ali b. Medînî’nin (öl. 234/848-849) düzenlediği imlâ meclisi için bir gün öncesinden yer tutan bir şahsın döndüğünde yer bulamama endişesiyle bulunduğu yerde altına serdiği şalına bevlettiğini gördüğünü anlatır. Bk. Hatîb el-Bağdâdî, el-Câmi', 2/138; Sem'ânî, Edebü'l-imlâ ve'l-istimlâ', 112-113.

53 İbrahim Sarıçam - Seyfettin Erşahin, İslâm Medeniyeti Tarihi (Ankara: Türkiye Diyanet Vakf1 Yayınları, 2007), 123-127.

54 Hatîb el-Bağdâdî, el-Câmi', 2/60; Sem'ânî, Edebü'l-imlâ ve'l-istimlâ', 42.

55 Hatîb el-Bağdâdî, el-Câmi', 2/13, 54 .

56 Sem'ânî, Edebü'l-imlâ ve'l-istimlâ', 74-75.

57 Hatîb el-Bağdâdî, el-Câmi', 2/57.

58 Sem'ânî, Edebü'l-imlâ ve'l-istimlâ', 48, 74, 84, 134, 179. 
160 । M. TANRIVERDİ / Rivayetlerin Muhafazasına ve Nakline Yönelik Entelektüel Bir İlgi: İmlâ Usûlü ve Hadis Literatürüne Yansımaları

düzenlerdi. Nitekim Dârekutnî (öl. 385/995) Bağdat'ta Ebu'l-Kâsım etTeymî (öl. 538/1143) ise İsfahan'da vefatlarından kısa bir süre önce kendi evlerinde hadis imlâsında bulunmuşlardır. ${ }^{59}$

Meşhur muhaddisler câmi ve ev gibi kapalı alanlar yerine daha kalabalık gruplara hitap eden alanlarda hadis imlâsında bulunmayı tercih etmişlerdir. Bu nedenle meclisler, zaman zaman çarşı, meydan, cadde ve sokak gibi açık alanlarda tertip edilmiştir. ${ }^{60} \mathrm{Bu}$ tür meclislerde imlâlar, câmilerde belirli vakitlerde gerçekleştirilenlerden farklı olarak değişken zamanlı bir takvime bağlı olarak düzenlenmiştir. Sözgelimi bir bölgede misafir olarak bulunan meşhur muhaddisler, gelen talepler doğrultusunda o bölgenin meşhur cadde, sokak ve meydanlarında imlâ meclisleri akdetmişlerdir. Bağdat Rusâfe Câmiî Avlusu, Basra Hüceym Caddesi ve Nişabur Meydanı gibi geniş ve açık alanlarda akdedilen toplantılara sayıları yüz binleri bulan geniş kitleler iştirak etmiştir. ${ }^{61}$

5. (11.) ve 6. (12.) yüzylllarda medrese ve dârülhadîslerin ortaya çıkması ile toplanma yeri ve zamanı bakımından imlâ meclislerinin daha sistematik bir hüviyet kazandığı söylenebilir. Kendi devirlerinin ihtisas merkezleri olarak nitelendirilebilecek bu özel müesseseler, zamanla daha farklı bölgelerde inşa edilmeye başlandı ve sayıları hızla artış gösterdi. ${ }^{62}$ Böylece sokak ve caddelerde düzenlenen imlâ oturumları son buldu. Atabeg Nureddîn Mahmud Zengî tarafından Şam'da kurulan ${ }^{63}$ ve kısa zamanda bölgenin ilim merkezi haline gelen Nûriye Medresesi'nde Ebû Muhammed b. Asâkir (öl. 600/1203) ve babası İbn Asâkir (öl. 571/1175) idarecilik yapmışlar, imlâ toplantılarını da bizzat bu müessesede gerçekleştirmişlerdir. İbn Hacer (öl. 852/1448) Şeyhûniyye, el-Cemâliyyetü'l-Cedîde ve Kemâliyye dârülhadislerinde

59 Sem'ânî, Edebü'l-imlâ ve'l-istimlâ', 67, 110.

60 Koçyiğit, Hadis Istılahları, 167.

61 Hatîb el-Bağdâdî, el-Câmi', 2/54; Sem'ânî, Edebü'l-imlâ ve'l-istimlâ', 16, 18.

62 Bunlar arasında Fâzıliyye, Urviyye, Eşrefiyye, Kürûsiyye, Nâsıriyye, Şükayşakiyye, Sükkeriyye, Nefîsiyye, Sâmeriyye, Devâdâriyye, Kâmiliyye dârülhadis müesseseleri sayılabilir. Bk. Nebi Bozkurt, "Dâru'l-Hadîs", Türkiye Diyanet Vakfı İslam Ansiklopedisi (İstanbul: TDV Yayınları, 1993), 8/528; S. Ory, "Dār al-Hadith", The Encyclopaedia of Islam (EI²), ed. E. J. Bosworth vd. (Leiden: Brill Press, 2004), 12/197. (Suppl)

63 S. Ory, "Dār al-Hadith”, 195. 
imlâ oturumları düzenlemiştir. Nevevî (öl. 676/1277) ise Eşrefiyye Dârülhadisi'nde toplantılar akdetmiştir. ${ }^{64}$

Hadis tarihinde özel bir öneme sahip olan ve kurumsal olarak hizmet veren dârülhadisler, uhdesinde tuttukları şeyhu'l-hadisler sayesinde bölgenin hadis kültürünün zenginleşmesine katk1 sağlamışlardır. ${ }^{65}$ Sözgelimi Bağdat'taki ünlü Müstansıriyye Medresesi, görevlendirilen her dört müderristen en az birinin şeyhü'l-hadîs olması esasına göre faaliyet göstermekte idi. ${ }^{66}$ Ayrıca dârülhadislere bağlı mescitlerde muayyen zamanlarda hadis okuma ve okutma vazifesini yerine getiren bir de hadis kârisi bulunmakta idi. Dolayısıyla bu müesseseler sayesinde imlâ toplantılarının daha düzenli ve resmî bir hüviyet kazandı̆̆ı söylenebilir.

İmlâ oturumları genellikle haftada bir kez düzenlenmiş ve erken dönemlerde belli bir güne tahsis edilmeyen bu durum bir gelenek halini almıştır. Şartların elverdiği ölçüde imlâ meclisleri umumiyetle haftalık olarak akdedilmiştir. Mümlîler cumartesi günü dışında haftada bir gün imlâ oturumu düzenlemişlerdir. Buna mukabil zamanla ilgi ve talebin artması ve ilmî hayatın canlanması ile bu toplantılar haftada iki kez düzenlenmeye başlamıştır. Bu bağlamda muhaddislerin Salı ve Cuma günleri' ${ }^{67}$ imlâ meclisi akdetmeleri mu'tad bir hal almaya başlamıştır. Ancak yolculuk, hastalık ve eser telifi gibi gerek mümlîden gerekse müstemlîlerden kaynaklanan çeşitli nedenlerle bu oturumlar zaman zaman aksamış; bazı mücbir sebeplerden ötürü zaman zaman imlâ toplantıları kesintiye uğramıştır.

Öte yandan bazı muhaddislerin yaşadıkları yerleşim birimlerinin koşulları, yer yer imlâ meclislerinin gün ve saatlerinde de değişikliğge gidilmesini gerektirmiştir. Örneğin Deylem ve Cîl havzasında yaşayan

64 Ebû Zekeriyyâ Yahyâ b. Şeref en-Nevevî, İşâdu tullâbi'l-hakâik ilâ ma'rifeti süneni hayri'l-halâik, thk. Abdü'l-Bârî es-Selefî (Medine: Mektebetü'l-eymân, 1987), 30.

65 Hâlid b. Yusuf b. Sa'd'ın (öl. 663/1265) İzziyye medresesinde, Muhammed b. Abdülmün'im el-Harrânî’nin (öl. 671/1273) Âlemiyye medresesinde, Ömer b. Yahyâ b. Ömer eş-Şâfiî̀nnin (öl. 690/1291) Zâhiriyye medresesinde, Hasan b. Alî b. Îsâ esSayrafî'nin (öl. 699/1300) de Fergana medresesinde şeyhu'l-hadîs oldukları zikredilmektedir. Bk. Ebû Abdillâh Şemsüddîn Muhammed ez-Zehebî, Târîhu'l-İslâm, thk. Beşşâr Avvâd Ma'rûf (Beyrut: Dâru'l-ğarbi'l-İslamî, 2003), 14/7.

${ }^{66}$ Zehebî, Târîhu'l-İslâm, 15/84, 15/230, 15/669, 15/904.

67 Kettânî, Hadis Literatürü, 339. 
162 | M. TANRIVERDİ / Rivayetlerin Muhafazasına ve Nakline Yönelik Entelektüel Bir İlgi: İmlâ Usûlü ve Hadis Literatürüne Yansımaları

Zeydî muhaddislerden İmâm Mürşîd Billâh Yahyâ (öl. 479/1086) sadece Pazartesi ve Perşembe günleri hadis imlâ meclisi akdetmiş ve bu oturumlarda yazdırdığı rivayetlerden oluşan eserler el-Emâlî elisneyniyye ve el-Emâlî el-hamîsiyye şeklinde meşhur olmuşlardır. ${ }^{68} \mathrm{Bu}$ bakımdan imlâ toplantıları için özel bir gün belirlenmediği, oturumun yerinin ve zamanının tayininde ise hoca, talebe ve katılımcılar açısından uygun şartların ve müsait zaman diliminin gözetildiği anlaşılmaktadır. Bunun yanı sıra akdedilen imlâ meclisi için birincil derecede o bölgenin sosyo-ekonomik koşulları ile iklim şartlarının da göz önünde bulundurulduğu söylenebilir.

\section{4. İmlâ Faaliyetlerinin Hadis Literatürüne Yansımalan}

İmlâ usulü, hoca-talebe arasında gerçekleşen hadis tahammül ve edâsına yönelik muteber bir yöntem olması bakımından uzun müddet muhaddislerin yoğun ilgisine mazhar olmuştur. Buna bağlı olarak emâlîler de erken dönemlerden itibaren hadislerin muhafazasında kayda değer bir fonksiyon icra etmişlerdir.

Emâlî kelimesi, imlâ veya ümliye kelimelerinin çoğuludur. Bu anlamda emâlî, hadis talebesinin muayyen vakitlerde şeyhinden işittiği rivayetleri bir araya getirme gayretinin bir ürünüdür. Emâlî kavramı sadece hadis ilmine has olmayıp fakihler, müfessirler, dil ve lügat âlimlerinin meşgul oldukları bilgileri ezberlerinden veya kitaplarından ilgili talebelere aktarıp yazdırmalarını konu edinen bir kavramdır. Hadislerin intikalinde önemli bir konuma sahip olan bu gelenek, rivayete konu olan haberlerin muhafazası için erken dönemlerde başvurulan güvenilir bir yöntem olarak önemli bir fonksiyon icra etmiştir.

Emâlîler, hadis tarihinin ilk asırlarında rivayetleri herhangi bir kriter gözetmeksizin derlemenin bir yöntemi olarak ortaya çıkmış ve bu tür eserlerde yaklaşık 6. (12.) yüzyıla kadar genellikle herhangi bir kriter

68 Seyyid Ahmed el-Hüseynî, Müellefâtü'z-Zeydiyye (Kum: Mektebetu Âyetullâhi'1Uzma, 1413), 1/153-154; Abdusselâm b. Abbâs el-Vecîh, A'lâmü'l-müellifinne'z-Zeydiyye (Amman: Müessesetu'l-İmam Zeyd b. Ali es-sekâfiyye, 1999), 1101. Sözü edilen matbu eserler için bk. Mürşid Billâh Yahyâ b. el-Huseyn, Kitâbu'l-Emâlî el-isneyniyye, thk. Abdullah b. Hammûd el-'İzzî, San'a: Müessesetü'l-imâm Zeyd b. Alî essekâfiyye, 1429/2008). 

of Imlā and Its Reflections to Hadith Literature | 163 gözetilmemiştir. Çünkü emâlîler, şeyhin tertip ettiği imlâ meclislerinde o anda yazdırdığı hadislerin kayda geçirilmesiyle oluşan eserlerdir. Bu bakımdan kendi içerisinde bir bütünlük arz ettiği söylenebilirse de çoğu zaman emâlîler, şeyhin arzu ettiği rivayet seçkisine sahip olmuşlardır. Öyle ki şeyhin, yerini ve zamanını ilan ettiği meclislerde çoğu zaman ne tür hadislerin imlâsının gerçekleştirileceği talebelerce bilinmemektedir. Özellikle hocanın ezberden hadis imlâsında bulunduğu oturumlarda rivayet tercihindeki tasarruf tamamen ona aittir. ${ }^{69}$

Kitaptan rivayetin önem kazandığı dönemlerde ise şeyhin bu tasarrufu nispeten azalmış ve imlâ edilen hadisler, muhtevası bakımından belirginlik kazanmıştır. Bu itibarla emâlî türü eserler, konu bütünlüğ̈üne göre incelendiğinde 6. (12.) yüzyılın bir kırılma noktası oluşturduğu söylenebilir. Zira bu yüzyılın başlarından itibaren uzayan senedler terk edilmeye başlanmış, kitaplara itimat artmış ve hafızadan rivayet yerine kitaptan rivayet oldukça yaygınlaşmıştır. Dolayısıyla mümlîler, düzenledikleri meclislerde belirli konulardaki hadisleri veya belirli kitaplardaki rivayetleri imlâ ettirmeye başlamışlardır.

Emâlî türü eserlerde hadisin imlâ yöntemiyle alındı̆̆ına işaret eden

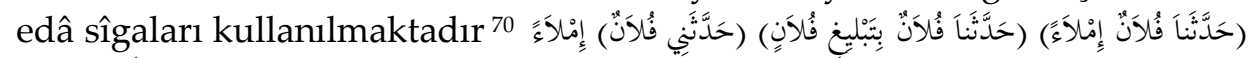

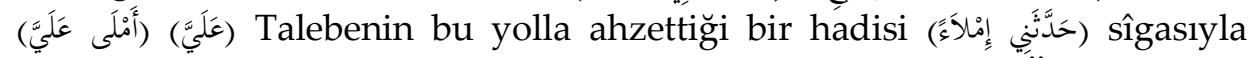
nakletmesi en yaygın rivayet lafzı olarak kabul edilmiştir. ${ }^{71}$ "Öyle ki hadis

69 Şeyhin hafızasından değil de kitaptan imlâda bulunduğu durumlarda bazı talebelerin yazmaktan imtina etmeleri, hadis naklinde hafızanın oldukça popüler bir güven kaynağı olduğunu göstermesi bakımından dikkat çekicidir. Bu uygulama, hafıza kusurlarına bağlı olarak birçok hataya sebebiyet verse de kitaba müracaat etmeksizin ezberden hadis imlâsında bulunmak erken dönemlerde sayginlık göstergesi idi. Bk. A'zamî, Studies, 18. Öyle ki İshâk b. Râhûye'nin (öl. 238/853) hadisleri hıfzından imlâ ettirdiği ve oturumun ardından yazdırdıklarını eksiksiz bir şekilde talebelerine tam olarak okuduğu zikredilmektedir. Bk. Hatîb el-Bağdâdî, Târîhu Bă̆gdad, 6/351.

70 Çakan, Hadis Usûlü, 52, 187.

71 Örnekler için bk. Müslim, “Cihâd ve siyer”, 2 (No: 1731) Ebû Abdillâh Muhammed b. Yezîd Mâce, es-Sünen, thk. Muhammed Fuâd Abdulbâkî (Beyrut: Dâru İhyai'lKütübi'l-'Arabî, ts.), "Taharet", 115 (No: 622); Ahmed b. Hanbel, el-Müsned, 1/553 (No: 540), 2/383 (No: 1203), 29/172 (No: 17629), 35/48 (No: 21117); Ebû Bekr Abdullah b. Muhammed b. Ebî Şeybe, el-Kitâbü'l-musanneffi'l-ehâdîs ve'l-âsâr, haz. Kemâl Yûsuf el-Hût (Beyrut: Dâru't-tâc, 1409/1989), 7/275 (No: 36037, 36039); Mücteba Uğur, 
164 | M. TANRIVERDİ / Rivayetlerin Muhafazasına ve Nakline Yönelik Entelektüel Bir İlgi:

İmlâ Usûlü ve Hadis Literatürüne Yansımaları

imlâsıyla meşgul olan ve bu tür oturumlar düzenleyen muhaddislerin

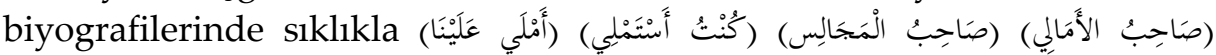
şeklinde ibarelere rastlanmaktadır. ${ }^{72}$

Çeşitli nedenlerle günümüze kadar ulaşamayan emâlî nüshalarının varlığı bilinmekle birlikte bugün dünyanın birçok kütüphanesinde risâle veya cüz şeklinde muhafaza edilen ve bu yöntemin kadîm geleneğinin izlerini taşıyan pek çok emâlî nüshası bulunmaktadir. ${ }^{73}$

Hadis edebiyatında emâlî türüne ilişkin eserlerin bu ilmin diğer türlerine nispetle daha fazla olduğu görülmektedir. Bu durumun öncelikli nedenlerinin başında hiç şüphesiz imlâ yönteminin sadece muhaddisler nazarında değil, düzenlenen imlâ meclislerine büyük bir katılım gösteren halk kitlesi nazarında da evleviyetli bir öneme sahip olması gelmektedir. İmlâ meclislerine gösterilen ilgi sayesinde hadis yazım faaliyetleri giderek hız kazanmıştır. Bu tür meclislerin sık sık düzenlenmesi de katılımcıların bir kısmını, kendilerine ait yazılı bir hadis cüzüne sahip olma konusunda teşvik etmiştir. Dolayısıyla bu meclislerde kayda geçen küçük çaplı cüz ve risâleler zamanla çoğalmış ve nicelik bakımından zengin bir literatür meydana gelmiştir.

Bununla beraber sözlükteki "yazdırma" anlamina atıfla hacmine bakmaksızın imlâ meclislerinde yazılan her bir materyale emâlî denilmekle birlikte bu kullanımın teknik olarak isabetli olmadığ1 anlaşılmaktadır. İmlâ usulündeki hedef her ne kadar hadis yazdırma olsa da bu eylemin uzun müddet yapılması ve yazım işinin süreklilik arzetmesi gerekmektedir. ${ }^{74} \mathrm{Bu}$ doğrultuda hadis ilmi özelinde emâlî türüne ait eserler incelendiğinde bunların önemli bir kısmının bu türün

“Edâ”, Türkiye Diyanet Vakfı Islâm Ansiklopedisi (İstanbul: TDV Yayınları, 1994), $10 / 388$.

72 Misal için bk. Zehebî, Siyeru a'lâmi'n-nübelâ', 15/381; Hatîb el-Bağdâdî, Târîhu Bă̆gdad, 2/20, 3/42, 11/131; Zehebî, Târîhu'l-İslâm, 7/328, 11/665.

73 Bu sahada telif edilen eserlerin yekûnu oldukça fazladır. Bk. Kettânî, Hadis Literatürü, 339-352; Mücteba Uğur, Hadis Edebiyatı (Ankara: TDV Yayınları, 1996), 75-78; Yüksel Efil, Hadis İmlâ Meclisleri (İstanbul: Marmara Üniversitesi, Sosyal Bilimler Enstitüsü, Yüksek Lisans Tezi, 1991), 85-115, 116-126.

74 Zira imlâya konu olan bir kitabı yahut hadisleri yazdırmak, onları yazacak olan talebeye uzun müddet okumayı gerektirmektedir. Bk. Sehâvî, Fethu'l-muğ̣̂s, 3/250. 

of Imlā and Its Reflections to Hadith Literature | 165

şekil şartlarını taşımadığı görülür. Çünkü bu eserlerde uzun soluklu bir hadis yazım faaliyeti söz konusu olmalıdır. Oysa meşhur bir muhaddisin ziyaretinde teberrüken yazdırılan veya bir kimsenin tek bir mecliste yazdığı birkaç hadis ile emâlîler için gereken uzun müddet meşguliyet şartı sağlanmış olmamaktadır. Nitekim hadis edebiyatında emâlî eserlerinin örnekleri zikredilirken imlâ, emâlî, meclis, mecâlîs, mücâlese, mücâlesât, ta'lîk veya nevâdîr ${ }^{75}$ gibi birbirinden kısmen farklı isimlendirmeler kullanılmıştır.

Emâlî türü eserlerin hangi kriterlere göre isimlendirildiği konusunda net bir malumat bulunmamakla birlikte imlâ toplantılarında yazılan malzemenin hacminin isim konusunda belirleyici olduğu anlaşılmaktadır. Çünkü emâlîler genellikle aralarında konu bütünlüğü olmayan çeşitli hadislerin bir araya getirilmesinden oluşmaktadır. Buna bağlı olarak ortaya çıkan eserler de konusuna göre değil, çoğunlukla mevcut malzemenin hacmine göre isimlendirilmişlerdir. Dolayısıyla imlâ faaliyetleri neticesinde ortaya çıan malzemelerin en hacimli olanlarına emâlî denilmiştir. Emâlîlere kıyasla daha az sayıdaki oturumda yazılan rivayet malzemesinin bir araya getirilmiş şekline meclis, bu toplantılarda kaydedilen en küçük hacimli eserlere ise cüz' adı verilmiştir. Nitekim Ebû Muhammed Hasan b. Ahmed enNîsâbûrî’nin (öl. 389/999) bu sahaya ilişkin vefatından iki sene önce meydana getirdiği Cüz' min selâsi mecâlis min emâlî adlı eseri söz konusu ayrıma örnek gösterilebilir. ${ }^{76} \mathrm{Bu}$ anlamda cüzlerden meydana gelen eserlere meclis, meclislerin bir araya getirilmesiyle oluşan eserlere de "emâlî" denilebilir.

Hadis edebiyatında bu eserlerin tamamı, aralarındaki teknik ayırıma bakılmaksızın, imlâya konu olmaları bakımından sözlük anlamına atıfla emâlî olarak anılmaktadır. Bu teknik ayrımdan sonra aşağıdaki başlıklarda ilgili literatüre işaret edilmiştir. Ancak emâlî eserleri, gerek mahtût gerekse matbu halde dünyanın birçok kütüphanesinde bulunmakta olup bu türün örnekleri hayli fazladır. Bu nedenle makalenin hacmini aşmamak adına ilgili literatürün tamamına yer verilmeden sadece teknik ayrıma yönelik örneklerle yetinilmiştir.

75 Kandemir, “Emâlî”, 70.

76 Fuat Sezgin, Târîhu't-türâsi'l-Arabî, çev. Mahmûd Fehmî Hicâzî (Riyad: Câmi'atü'lİmâm Muhammed b. Suûd el-İslâmiyye, 1411/1991), 1/432. 
166 I M. TANRIVERDİ / Rivayetlerin Muhafazasına ve Nakline Yönelik Entelektüel Bir İlgi: İmlâ Usûlü ve Hadis Literatürüne Yansımaları

\subsection{Emâlîler}

Emâlîler imlâ toplantılarında ortaya çıkan en geniş hacimli eserler olup genellikle "emâlî fi'l-hadîs" veya "emâlî" şeklinde anılmışlardır. Mesela Ebû Bekir Muhammed b. Muhammed b. Süleymân el-Vâsitî'nin (öl. 312/925) Emâlî fi'l-hadîs adlı eseri ${ }^{77}$ ile Ebû Bekir Yûsuf b. el-Kâsım b. Yûsuf el-Meyânecî'nin (öl. 375/985) Dımaşk'ta imlâ ettiği Emâlî fi'l-hadîs adlı eseri78 örnek olarak zikredilebilir. Bunun yanı sıra İbn Asâkir'in (öl. 571/1176) Dımaşk'taki meşhur Emeviyye Câmii'nde akdettiği 400'ü aşkın imlâ oturumunda yazdırdığı rivayete konu malzemenin bir araya getirildiği eseri de Emâlî adıyla kayda geçmiştir. ${ }^{79}$

Öte yandan bu eserlerin bir kısmı imlâyı gerçekleştiren muhaddisin ismine nispetle isimlendirilirken bir kısmı da imlânın yapıldığı bölgeye, medreseye veya dârülhadise nispetle isimlendirilmiştir. Örneğin Şeyh Sadûk olarak bilinen İbn Bâbeveyh elKummî'nin (öl. 381/991) doksan yedi meclisten oluşan Emâli's-Sadûk adlı eseri, mümlînin ismine nispetle isimlendirilmiştir. ${ }^{80}$ Benzer şekilde Selçuklu veziri Nizâmülmülk'ün (öl. 485/1092) Bağdat'ta Câmiu'l-Mehdî ve Nizâmiye Medresesi'nde imlâ ettirdiği Emâlî Nizâmülmülk el-vezîri'sSelcûkî fi'l-hadîs eseri de mümlîye nispetle adlandırılmıştır. ${ }^{81}$

Mümlîye nispetle isimlendirilen emâlî eserlerinden birisi de Zeydî muhaddislerden Ahmed b. Îsâ b. Zeyd'e (öl. 247/861) aittir. Onun Kitâbu'l-Emâlî olarak bilinen eserinin asıl adı Emâlî Ahmed b. Isâ olup Câmi'u'l-'ulûm âli Muhammed ve Kitâbu'l-'ulûm gibi isimlerle

77 Sezgin, Târîhu't-türâsi'l-Arabî, 1/339-340.

78 Kâtib Çelebî, Keşfü'z-zunûn an esâmi'l-kütüb ve'l-fünûn, haz. Şerafettin Yaltkaya - Rıfat Bilge (Beyrut: Dâru ihyâi't-türâsi'l-Arabî, ts.), 1/162; Sezgin, Târîhu't-türâsi'l-Arabî, $1 / 410$.

79 Kâtib Çelebî, Keşfü'z-zunûn, 1/162; Kettânî, Hadis Literatürü, 339-340.

80 Ebû Ca'fer Muhammed b. Alî b. el-Hüseyn b. Mûsâ b. Bâbeveyh el-Kummî, Emâli'sSadûk, haz. Hüseyin A'lemî (Beyrut: Müessesetü'l-a'lemî li'l-matbû'ât, 1430/2009).

81 Hadis ilmiyle meşgul olmayı önemseyen siyasetçilerden biri olan Nizâmülmülk'ün 480/1087' de Bağdat'ta akdettiği imlâ meclislerinde yazdırdığı rivayet malzemesi için bk. Ziriklî, "Nizâmülmülk", 2/202; Kandemir, "Emâlî", 70-72'den naklen: "Abdülhâdî Rızâ, "Emâlî Nizâmülmülk el-vezîri's-Selcûkî fi'l-hadîs", Mecelletü ma'hedi'l-mahtûtâti'l-'Arabiyye-Kahire 5 (1959), 349-378" 
M. TANRIVERDİ / An Intellectual Interest for the Protection and Narration of Hadiths: The Method of Imlā and Its Reflections to Hadith Literature | 167

bilinmektedir. ${ }^{82}$ Emâlı̂̀nin Zeydî çevreler üzerindeki ehemmiyetli ve evleviyetli konumundan ötürü 4. (10.) yüzyıl Zeydî imamlarından Mansûr-Billâh Kâsım b. Alî (öl. 393/1003), ona Bedâi'u'l-envâr fi mehâsini'l-âsâr ismini vermiştir. 7. (13.) yüzyıl Zeydi imamlarından Mansûr-Billâh Abdullah b. Hamza (öl. 614/1217) da Bedâi'u'l-envâr fi mehâsini'l-ahbâr ve'l-âsâr şeklinde isimlendirmiştir. ${ }^{83}$

İbn Hacer el-Askalânı̂'nin (öl. 852/1449) de bu türe ilişkin emâlîsi bulunmaktadır. Nitekim kendisi Kâmiliyye Dârülhadisi ile Kahire'deki Şeyhûniyye ve Baybarsiyye medreselerinde uzun seneler imlâ oturumları düzenlemiş olup vefatına kadar büyük bir titizlikle yürüttüğü imlâ meclisleri 1150 oturuma ulaşmıştır. Bunlar arasından İbnü'l-Hâcib'in el-Muhtasar'ı ile Nevevî'nin el-Ezkâr'ındaki hadislerin tahricinin yapıldığ 270 meclisten oluşan eseri, ait olduğu medreseye nispetle el-Baybarsiyye yahut el-Emâli'l-Misriyye el-Baybarsiyye şeklinde anılmaktadır. ${ }^{84}$ Ayrıca 836/1433'te Halep'te bulunduğu sırada akdettiği yedi meclisten oluşan eseri de yine imlânın düzenlendiği medreseye nispetle Emâli'l-Halebiyye adıyla anılmaktadır. ${ }^{85}$ Benzer şekilde İbnü'şŞıhne'nin (öl. 890/1485) el-Emâli'l-muhibbiyye bi'l-medreseti'l-Mü'eyyediyye

82 Ebû Abdillâh İzzüddîn Muhammed b. İbrâhîm b. Alî el-Yemânî, el-'Avâsım ve'lkavâsım fi'z-zebbi 'an sünneti Ebi'l-Kâsım, thk. Şu'ayb el-Arnavûd (Beyrut: Müessesetu'r-risâle, 1996), 3/151, 232; Vecîh, A'lâmü'l-müellifine'z-Zeydiyye, 152; Seyyid Ahmed el-Hüseynî, Müellefâtü'z-Zeydiyye, 2/281.

83 Ebü'l-Hüseyin Mecdüddin b. Mansûr el-Müeyyedî, Levâmi'u'l-envâr (Sa'de: Mektebetü't-türâsi'l-İslâmiyye, 1993), 1/333; Ebû Abdillâh Muhammed b. Ali b. elHüseyin b. 'Alevî, el-Câmiu'l-kâfi fì fikhi'z-Zeydiyye, thk. Abdullâh b. Hamûd el-'İzzî (b.y.: Müesesetü'l-Mustafâ es-Sekâfiyye, 2014) 193; Kadir Demirci, Zeydiyye ve Hadis (Ankara: Gece Akademi Yayınları, 2019), 66. Esere ve müellife ilişkin ayrıntılı bilgi için bk. Mustafa Tanrıverdi, “Ahmed b. İsâ b. Zeyd ve Emâlî Adlı Hadis Eseri Üzerine Bir İnceleme", Eskişehir Osmangazi Üniversitesi İlahiyat Fakültesi Dergisi 6/11 (Eylül 2019), 309-342.

84 Eserin kendi içerisinde çeşitli parçaları Tahrîcü'l-Ezkâr, Emâli'l-Ezkâr, Emâliyyü'lmuhrace alâ muhtasarı İbni'l-Hâcib el-aslî ve Netâ'icü'l-efkâr fì tahrîci ehâdîsi'l-Ezkâr gibi farklı isimlerle zikredilmektedir. Bk. Kandemir, "Emâlı̂”, 71'den naklen; Kandemir, “İbn Hacer el-Askalânî”, 521'den naklen; Kettânî, Hadis Literatürü, 343.

85 Kâtib Çelebî, Keşfü'z-zunûn, 1/162; Kettânî, Hadis Literatürü, 343. 
168 | M. TANRIVERDİ / Rivayetlerin Muhafazasına ve Nakline Yönelik Entelektüel Bir İlgi: İmlâ Usûlü ve Hadis Literatürüne Yansımaları

adlı eseri de Kâhire'deki Müeyyidiyye Medresesi'nde gerçekleştirilen hadis imlâlarını ihtiva etmesinden ötürü bu isimle anılmaktadır. ${ }^{86}$

\subsection{Meclisler}

İmlâ toplantılarının her bir oturumuna ve bu oturumlarda yazıya geçirilen eserlere meclis adı verilmektedir ${ }^{87}$ İmlâ faaliyetleri neticesinde ortaya çıkan mahsüllerden biri de bunlardır. Bu türe ait bazı eserler ait olduğu imlâ meclisine nispetle meclis (mecâlis) veya mücâlese (mücâlesât) şeklinde anılmışlardır. Nitekim Ebû Bekir eş-Şâfiî̀nin (öl. 354/965) bu türdeki eseri Meclis olarak adlandırılırken ${ }^{88}$ Ebû Bekir edDîneverî'nin (öl. 310/923) bu türe dair eseri el-Mücâlese olarak adlandırılmıştır. ${ }^{89}$ Sa'leb olarak bilinen Ebü'l-Abbâs Ahmed b. Yahyâ eşŞeybânî'nin (öl. 291/904) eseri de Mücâlesât şeklinde ${ }^{90}$ zikredilmektedir.

$\mathrm{Bu}$ türdeki eserlerde her bir meclis müstakil bir ders kabul edildiğinden kendi içerisinde farklı sayılarda meclis ihtiva eden eserlere mecâlis denilmektedir. Örneğin Ebü'l-Kâsım Alî b. Muhammed elBasrî'nin bu türdeki eseri Meclis min emâlî adıyla ${ }^{91}$ anılırken Ebû Muhammed İbn Sâid el-Hâşimî'nin (öl. 318/930) eseri Mecâlis şeklinde ${ }^{92}$ anılmaktadir.

Mecâlis türü eserler de kendi içerisinde farklı sayılarda meclisler içermekte olup isimlendirmelerde zaman zaman bu hususun gözetildiğ $i$ anlaşılmaktadır. Örneğin Horasanlı muhaddis Ebü'l-Abbâs Muhammed el-Esam'ın (öl. 346/957) bu türdeki eseri Meclisân min emâlî iken ${ }^{93}$ Assâl olarak bilinen Ebû Ahmed Muhammed el-İsfahânî'nin (öl. 349/960) eseri Selâsetü mecâlis min emâlî şeklinde isimlendirilmiştir. Benzer şekilde

86 Konuyla ilgili çalışma için bk. Vahdettin Yağmur, Hadis Literatüründe Emâlîler ve Ebu'l-Fazl İbnu'ş-Şıhne'nin 'el-Emâli'l-Muhıbbiyye' Adlı Eserinin Edisyon Kritiği (İzmir: Dokuz Eylül Üniversitesi, Sosyal Bilimler Enstitüsü, Yüksek Lisans Tezi, 2011), 31-49.

87 Aydınlı, "Meclis", 173.

88 Sezgin, Târîhu't-türâsi'l-Arabî, 1/384; Ziriklî, "Ebû Bekir eş-Şafiî̀", 6/224.

89 Zehebî, Siyeru a'lâmi'n-nübelâ', 2/352; Kâtib Çelebî, Keşfü'z-zunûn, 2/1591.

90 Kâtib Çelebî, Keşfü'z-zunûn, 2/1591; Ziriklî, “Sa'leb”, 1/267-268.

91 Sezgin, Târîhu't-türâsi'l-Arabî, 1/322.

92 Sezgin, Târîhu't-türâsi'l-Arabî, 1/347.

93 Sezgin, Târîhu't-türâsi'l-Arabî, 1/372. 
M. TANRIVERDİ / An Intellectual Interest for the Protection and Narration of Hadiths: The Method of Imlā and Its Reflections to Hadith Literature | 169

Taberânî'nin (öl. 360/971) eseri Erba'atü mecâlis min mecâlisi't-Taberânî, ${ }^{94}$ Ebû Muhammed el-Hallâl'ın (öl. 439/1047) eseri ise Aşeratü mecâlis olarak zikredilmektedir. ${ }^{95}$

\subsection{Cüz'ler}

Sözlükte nasip, pay, kıt’a gibi anlamlara gelen cüz' (çoğulu: eczâ'); bir bütünü meydana getiren en küçük parça anlamına gelir. ${ }^{96}$ Hadis ilminde belirli bir kimseye yahut konuya dair rivâyetleri ihtiva eden küçük hacimli eserlere cüz adı verilmektedir. ${ }^{97} \mathrm{Bu}$ anlamda emâlî türüne dair bazı eserler, küçük hacimli eserler olmaları sebebiyle cüz şeklinde anılmaktadır. Örneğin Ahmed b. Habîb eş-Şücâî’ye (öl. 184/800?) nispet edilen beş varaklık eserin ismi Cüz' mine'l-emâl $\hat{\imath}^{98}$ iken Ebu'l-Ferec elGûrî'nin (öl. 239/853) bu sahaya dair dört varaklık eserinin adı Cüz' fihi meclisün min imlâihı̂' dir. ${ }^{99}$

Kur'an-1 Kerîm'in otuz cüz olmasına atıfla bir cüzün on varak (yirmi sayfa) olduğu ileri sürülmüşse de bu hususta asgari bir sınırın olmadığ1 ve cüzlerin hacimleri konusunda muayyen bir ölçünün bulunmadığ1 anlaşılmaktadır. ${ }^{100}$ Öyle ki emâlî cüzleri incelendiğinde bu eserlerin, birbirinden farklı hacimlere sahip oldukları ve birbirlerinden farklı sayılarda rivayet ihtiva ettikleri görülmektedir. Nitekim Nesâî'nin (öl. 303/915) Cüz' fihi meclisân min imlâ' eserinde toplamda 47 rivayet yer alırken ${ }^{101}$ Ebû İshâk İbrâhîm b. Abdissamed el-Bağdâdî'nin (öl. 325/937) el-Cüzü'l-evvel min emâlî eserinde toplamda 111 rivayet bulunmaktadır. ${ }^{102}$

94 Mehmet Görmez, “Taberânî”, Türkiye Diyanet Vakfı İslam Ansiklopedisi (İstanbul: TDV Yayınları, 2010), 39/312.

95 Sezgin, Târîhu't-türâsi'l-Arabî, 1/480; Ziriklî, "el-Hallâl”, 2/213.

96 İbn Manzûr, "cze", 1/45-47; Zebîdî, "cze”, 1/171-172.

97 Aydınlı, “Cüz", 51.

98 Sezgin, Târîhu't-türâsi'l-Arabî, 1/177.

99 Sezgin, Târîhu't-türâsi'l-Arabî, 1/209.

100 Bunun nedeni cüz hesabıyla verilen ölçülerin birbirinden farklı olmasıdır. M. Yaşar Kandemir, "Cüz", Türkiye Diyanet Vakfı İslam Ansiklopedisi (İstanbul: TDV Yayınları, 1993), 8/148.

101 Ebû Abdirrahmân Ahmed b. Şuayb en-Nesâî, Cüz' fîhi meclisân min imlấi (el-Emâlî), thk. Ebû İshâk el-Huveynî el-Eserî (Riyad: Dâru İbni'l-Cevzî, 1415/1994), 32-92.

102 Hatîb el-Bağdâdî, Târîhu Băğdad, 6/135-137; Zehebî, Siyeru a'lâmi'n-nübelâ', 15/71-73; Kâtib Çelebî, Keşfü'z-zunûn, 1/162; Ziriklî, "İbn Abdissamed", 1/47; Sezgin, Târîhu'ttürâsi'l-Arab̂̂, 1/351. Bahse konu hadis cüzüne dair çalışma için bk. Mustafa Karataş, 
170 । M. TANRIVERDİ / Rivayetlerin Muhafazasına ve Nakline Yönelik Entelektüel Bir İlgi: İmlâ Usûlü ve Hadis Literatürüne Yansımaları

Dolayısıyla imlâya konu rivayetleri bir araya getiren küçük çaplı eserler olan cüzlerin birbirinden farklı nicelikte eserler olduğu söylenebilir.

Diğer taraftan emâlî cüzlerini de kendi içerisinde râvi veya meclis merkezli bir tasnîfe tabi tutmak mümkündür. Bu itibarla emâlîler, tek bir râvinin bütün rivâyetlerini içerebileceği gibi, bir râvinin birçok mecliste imlâlarının tamamını da ihtiva edebilir. Yine bir muhaddisin sadece tek bir mecliste imlâ ettirdiği hadisleri içerebileceği gibi, birden fazla muhaddisin akdettikleri meclislerinde yazdırdıkları rivayetleri de içerebilir. Tabiatıyla bu tür eserlerde dikte ettirilen hadisler genellikle tek bir konu etrafında şekillenmemiştir. Nitekim Mehâmilî’ye (öl. 330/941) ait on altı muhtasar cüzden oluşan Emâlı̂'nin yedinci cüz'ünde aralarında konu bütünlügü olmayan altmış beş hadis bulunmaktadır. $\mathrm{Bu}$ hadis cüz'ünde nübüvvetin kırk altı şubesinden birinin rüya olduğu, müjdeli bir haber karşısında Rasulullah'ın (s.a.v) şükür secdesi yaptığı, tavla oynamanın isyan sayıldığı, Allah'ın ahirette nasıl görüleceği, Hz. Âdem'in cenazesinin yıkandığı, yatmadan evvel okunacak faziletli dualar, fakirin zenginden önce cennete gireceği, münâfık kimseye 'efendim' denmemesi gerektiği, ilk Müslüman'ın Hz. Ebû Bekir olduğu, hayânın hayır ve bereket getireceği, evlilikte doğurgan kadının tercih edilmesi gerektiği gibi birbirinden bağımsız konularda hadisler imlâ edilmiştir. ${ }^{103}$

\subsection{Diğerleri}

Emâlî, meclis ve cüz şeklindeki isimlendirmelerin yanı sıra Şâfiî âlimlerin hadis imlâsıyla meydana gelen eserleri "ta'lîk" şeklinde de adlandırdıklarından söz edilmektedir. ${ }^{104}$ Ancak bu isimle anılan eserlerin müşterek özelliğinin hadis ilminden ziyade Arap dili ve edebiyatı ile ilgili olduğu ve zaman zaman aynı sahadaki ürünlere "nevâdir" de denildiği görülmektedir. Nitekim İbn Düreyd'in (öl.

İbrahîm b. Abdissamed el-Hâşimî ve "el-Emâlî" İsimli Hadis Cüz'ü (İstanbul: Marmara Üniversitesi, Sosyal Bilimler Enstitüsü, Yüksek Lisans Tezi, 1989).

103 Geniş bilgi için bk. Faruk Koçak, İstanbul Kütüphanelerindeki Hadis Cüzleri (İstanbul: Marmara Üniversitesi, Sosyal Bilimler Enstitüsü, Doktora Tezi, 1995), 278. Bahse konu hadis cüzüne dair çalışma için bk. Nevzat Sabri Akın, Mehâmilî ve "Kitâbü'ddua" Ísimli Hadis Cüz'ü (İstanbul: Marmara Üniversitesi, Sosyal Bilimler Enstitüsü, Yüksek Lisans Tezi, 1990).

104 Kâtib Çelebî, Keşfü'z-zunûn, 1/161. 

of Imlā and Its Reflections to Hadith Literature | 171 321/933) dil ve edebiyat sahasında imlâ ettirdiği ve nevâdir olarak da bilinen et-Ta'lîk min emâlî isminde bir eseri bulunmaktadır. Bu eser, Ebû Müslim Muhammed el-Kâtib hocasına ait eserden Arap diline ilişkin bazı müstakil konulardaki nakilleri bir araya getirmek suretiyle meydana getirdiği bir seçkiden ibarettir. ${ }^{105}$

Öte yandan nevâdir ve emâlî çatısı altında mütalaa edilebilecek eserlerden yapılan seçkiler, "müntekâ" veya "muhtârât" şeklinde de anılmaktadır. Örneğin İbn Merdûye olarak bilinen Ebû Bekir Ahmed b. Mûsâ el-İsfahânî'nin (öl. 410/1020), hocası Ebû Abdillâh Muhammed b. İbrâhim el-Cürcânî'nin (öl. 408/1018) Emâlî́sinden yaptığ1 seçki, Muhtârât mine'l-Emâlî şeklinde anılmaktadır. ${ }^{106}$ Benzer şekilde Kâtip Çelebî, Ebü'l-Fazl Muhammed b. Muhammed'in (öl. 334/945), emâlî ve nevâdir türündeki yaklaşık üç yüz eserden elde ettiği malumatları Müntekâ isimli bir seçkide bir araya getirdiğinden söz etmektedir. ${ }^{107}$

Bu bağlamda emâlî edebiyatı içerisinde "ta'lîk" veya "nevâdir" şeklindeki isimlendirmenin hadis imlâ faaliyetleri neticesinde ortaya çıkan ürünlere verilen isimlerden kısmen bağımsız olduğu söylenebilir. $\mathrm{Bu}$ konuda kesin bir ayrım olmamakla birlikte ekseriyetle dil ve edebiyat sahasına dair nakillerin imlâsıyla vücuda gelen emâlî eserlerinin veya bunlardan elde edilen derleme ve seçkilerin bu isimlerle anıldığı anlaşılmaktadır.

\section{Sonuç}

İmlâ, hadislerin muhafazasını ve güvenilir naklini esas alan bir usûl olması bakımından hadis tahammül yolları arasında muteber bir yöntem olarak görülmüştür. Bu metot, hadis tarihinde sözlü kültürden yazılı kültüre geçiş sürecinde rivayet malzemesinin korunması ve sonraki nesillere intikali açısından kayda değer bir fonksiyon icra etmiştir. İmlâ meclisleri sayesinde muhaddisler, rivayet hakkına sahip oldukları hadis malzemelerini güvenilir bir yolla talebelere aktarma fırsatı elde etmişlerdir.

105 Ebû Bekir Muhammed b. el-Hasen b. Düreyd, et-Ta'lîk min Emâlî İbn Düreyd, thk. Mustafa es-Senûsî (Kuveyt: el-Meclisü'l-vatanî li's-sekâfe ve'l-fünûn ve'l-âdâb, 1404/1984).

106 Sezgin, Târîhu't-türâsi'l-Arabî, 1/462.

107 Kâtib Çelebî, Keşfü'z-zunûn, 2/1851-1852. 
172 | M. TANRIVERDİ / Rivayetlerin Muhafazasına ve Nakline Yönelik Entelektüel Bir İlgi:

İmlâ Usûlü ve Hadis Literatürüne Yansımaları

Ne var ki her şeyden önce söz konusu yöntemin güvenilirliği, hoca ve talebenin güvenilirliğine bağlıdır. Zira bu güveni sağlayan yegane unsur, hoca ve talebenin mülâkî oluşudur. Hoca ile görüşme imkânının bulunmadığı geniş katılımlı oturumlarda özellikle yazı konusunda ehliyetli olmayan talebelerin yazdıkları cüzlerin, asıl nüsha ile karşılaştırılıp tashih edilmediği durumlarda hataların kaçınılmaz olduğu anlaşılmıştır.

Hadis literatüründe imlâ faaliyetleri neticesinde ortaya çıkan emâlî türü eserlere ilişkin belirli bir tasnîf metoduyla müstakil bir iç düzenden söz etmenin mümkün olmadığı görülmüştür. Söz gelimi müsnedler râvi adları, câmi ve sünenler ise belli konular etrafında düzenlenmesine rağmen emâlîlerde böyle bir yöntemin takip edilmediği anlaşılmıştır.

Emâlî çatısı altında mütalaa edilebilecek türdeki eserlerde isimlendirmenin neye göre yapıldığı konusunda net bir kriter olmadığ saptanmıştır. Dolayısıyla bu tür eserlerin umumiyetle imlâya konu olan rivayet malzemesinin hacmine nispetle isimlendirildiği ve buna göre genellikle büyükten küçüğe doğru emâlî, meclis, cüz şeklinde anıldıkları tespit edilmiştir.

İmlâ metodunun, hadis ilmine yönelik hâkim bakış açısını belirlemede ilgili dönem açısından önemli bir tespit aracı olabileceği anlaşılmıştır. Nitekim hicrî 4. (10.) yüzyıla kadar imlâ toplantılarındaki asıl amaç, genellikle ihtiva ettiği mana ve hükmü anlama gayretinden ziyade hadislerin senedleriyle birlikte eksiksiz olarak nakledilmesi iken 5. (11.) yüzyılla birlikte fıkhî içerikli rivayet malzemesini bir araya getirmek ve fıkhî derinlikli hadislerin imlâsı ile toplumun genel ahlaki yapısına katkı sunmak amaçlanmıştır.

Son olarak Bağdat'tan Herat'a, Dımaşk'tan Nişabur'a kadar birçok bölgede muhaddisleri ve onların bu faaliyetlerini yakından takip eden entelektüel kitleyi yaklaşık on asır boyunca "hadis" paydasında bir arada tutan imlâ meclislerinin hem hadis kültürüne hem de farklı isim ve unvanlarla anılan edebî mahsülleri ile hadis literatürüne önemli katkılar sağladığı görülmüştür. 


\section{Kaynakça}

Abdusselâm b. Abbâs el-Vecîh. A'lâmü'l-müellifinne'z-Zeydiyye. Amman: Müessesetu'l-İmam Zeyd b. Ali es-sekâfiyye, 1999.

Abdülhâdî Rızâ. "Emâlî Nizâmülmülk el-vezîri's-Selcûkî fi'l-hadîs". Mecelletü ma'hedi'l-mahtûtâti'l-'Arabiyye-Kahire 5 (1959), 349-378.

Ahmed b. Hanbel, Ebû Abdillâh Ahmed b. Muhammed. el-Müsned. thk. Şu'ayb el-Arnaût - Âdil Mürşid. 50 Cilt. Beyrut: Müessesetu'rrisâle, ts.

Ahmed b. Hanbel, Ebû Abdillâh Ahmed b. Muhammed. Kitâbü'l-'ilel ve ma'rifeti'r-ricâl. thk. Vasiyullah b. Muhammed Abbâs. 3 Cilt. Riyad: Dâru'l-hânî, 2. Basım, 1422/2001.

Akın, Nevzat Sabri. Mehâmilî ve "Kitâbü'd-dua" İsimli Hadis Cüz'ü. İstanbul: Marmara Üniversitesi, Sosyal Bilimler Enstitüsü, Yüksek Lisans Tezi, 1990.

Aydınlı, Abdullah. "İmlâ". Türkiye Diyanet Vakfı İslam Ansiklopedisi. 22/225-226. İstanbul: TDV Yayınları, 2000.

Aydınlı, Abdullah. Hadis Istılahları Sözlüğü. İstanbul: MÜ İlahiyat Fakültesi Vakfı Yayınları, 3. Basım, 2009.

A'zamî, Muhammed Mustafa. Studies in Hadith Methodology and Literature. Riyad: y.y., 1977.

Başaran, Selman - Sönmez, Mehmet Ali. Hadis Tarihi ve Usûlü. b.y.: Esra Fakülte Kitabevi, 1993.

Bozkurt, Nebi. "Dâru'l-Hadîs". Türkiye Diyanet Vakfi İslam Ansiklopedisi. 8/527-529. İstanbul: TDV Yayınları, 1993.

Buhârî, Ebû Abdillâh Muhammed b. İsmâîl. el-Câmi'u's-sahîh. nşr. Muhammed Züheyr b. Nasr. 9 Cilt. b.y.: Dâru tavki'n-necât, 2. Basim, 1422/2001.

Cevherî, Ebû Nasr İsmâîl b. Hammâd. es-Sihâh tâcü'l-lüga ve sihâhı'l'Arabiyye. thk. Ahmed Abdulgafûr Attâr. 7. Cilt. Beyrut: Dâru'l'ilm li'l-melâyîn, 4. Basım, 1990.

Çakan, İsmail Lütfi. Hadis Usûlü. İstanbul: MÜ İlahiyat Fakültesi Vakfı Yayınları, 23. Basım, 2010.

Dârimî, Ebû Muhammed Abdullah b. Abdirrahmân b. el-Fazl. Sünenü'dDârimî. thk. Huseyn Selîm Esed. 4 Cilt. Riyâd: Dâru'l-Muğnî, $1421 / 2000$. 
174 | M. TANRIVERDI / Rivayetlerin Muhafazasına ve Nakline Yönelik Entelektüel Bir İlgi: İmlâ Usûlü ve Hadis Literatürüne Yansımaları

Demirci, Kadir. Zeydiyye ve Hadis. Ankara: Gece Akademi Yayınları, 2019.

Ebû Abdillâh el-Kûfî, Muhammed b. Ali b. el-Hüseyin b. 'Alevî. elCâmiu'l-kâfí fì fikhi'z-Zeydiyye. thk. Abdullâh b. Hamûd el-'İzzî. b.y.: Müesesetü'l-Mustafâ es-Sekâfiyye, 2014.

Ebû Zehv, Muhammed. Hadis ve Hadisçiler. çev. Selman Başaran Mehmet Ali Sönmez. İstanbul: Ensar Neşriyat, 2016.

Efil, Yüksel. Hadis İmlâ Meclisleri. İstanbul: Marmara Üniversitesi, Sosyal Bilimler Enstitüsü, Yüksek Lisans Tezi, 1991.

Görmez, Mehmet. "Taberânî". Türkiye Diyanet Vakfı İslam Ansiklopedisi. 39/310-312. İstanbul: TDV Yayınları, 2010.

Hatîb el-Bağdâdî, Ebû Bekr Ahmed b. Alî. el-Kifâye fî ilmi'r-rivâye. thk. Ebû Abdillâh es-Sûrkî - İbrâhîm Hamdî el-Medenî. Medine: elMektebetü'l-'ilmiyye, 1357.

Hatîb el-Bağdâdî, Ebû Bekr Ahmed b. Alî. el-Câmi' li ahlâki'r-râvî ve âdâbi's-sâmi'. thk. Mahmûd Tahhân. 2 Cilt. Riyâd: Mektebetü'lma'ârif, 1983.

Hatîb el-Bağdâdî, Ebû Bekr Ahmed b. Alî. Şerefu ashâbi'l-hadîs. thk. M. Said Hatiboğlu. Ankara: AÜ İlahiyat Fakültesi Yayınları, 1972.

Hatîb el-Bağdâdî, Ebû Bekr Ahmed b. Alî. Takyîdü'l-'ilm. thk. Yûsuf el-Iş. b.y.: Dâru ihyâi sünneti'n-nebeviyye, ts.

Hatî̉b el-Bağdâdî, Ebû Bekr Ahmed b. Alî . Târîhu Bağdad. thk. Mustafa Abdülkâdir 'Atâ. 24. Cilt. Beyrut: Dâru'l-kütübi'l-'ilmiyye, 1417.

İbn Abdilberr, Ebû Ömer Cemâlüddin Yûsuf en-Nemerî. Câmi'u beyâni'lilm ve fadlih. thk. Ebü'l-Eşbâl ez-Züheyrî. 2 Cilt. Kahire: Dâru'lharameyn, ts.

İbn Bâbeveyh, Ebû Ca'fer Muhammed b. Alî b. el-Hüseyin el-Kummî. Emâli's-sadûk. haz. Hüseyin A'lemî. Beyrut: Müessesetü'l-a'lemî li'l-matbû'ât, 1430/2009.

İbn Düreyd, Ebû Bekir Muhammed b. el-Hasen. et-Ta'lîk min Emâlî İbn Düreyd. thk. Mustafa es-Senûsî. Kuveyt: el-Meclisü'l-vatanî li'ssekâfe ve'l-fünûn ve'l-âdâb, 1404/1984.

İbn Ebî Hâtim, Ebû Muhammed Abdurrahmân b. Muhammed. el-Cerh ve't-ta‘dîl. 9. Cilt. Beyrut: Dâru'l-kütübi'l-'ilmiyye, 1372/1953. 
M. TANRIVERDI / An Intellectual Interest for the Protection and Narration of Hadiths: The Method of Imlā and Its Reflections to Hadith Literature | 175

İbn Ebî Şeybe, Ebû Bekr Abdullah b. Muhammed el-Kûfî. el-Kitâbü'lmusannef fi'l-ehâdîs ve'l-âsâr. haz. Kemâl Yûsuf el-Hût. 7 Cilt. Beyrut: Dâru't-tâc, 1409/1989.

İbn Mâce, Ebû Abdillâh Muhammed b. Yezîd. es-Sünen. thk. Muhammed Fuâd Abdulbâkî. 3 Cilt. Beyrut: Dâru İhyai'l-Kütübi'l'Arabî, ts.

İbn Manzûr, Ebü'l-Fadl Cemâlüddîn Muhammed. Lisânü'l-'Arab. 15 Cilt. Beyrut: Dâru Sadr, ts.

İbnu's-Salâh, Osmân b. Abdirrahmân b. Mûsâ eş-Şehrezûrî. Ulûmu'lhadîs. thk. Nureddin Itır. Beyrut: Dâru'l-fikr, 1406/1986.

İbnü'l-Vezîr, Ebû Abdillâh İzzüddîn Muhammed b. İbrâhîm el-Yemânî. el-'Avâsım ve'l-kavâsım fi'z-zebbi 'an sünneti Ebi'l-Kâsım. thk. Şu'ayb el-Arnavûd. Beyrut: Müessesetu'r-risâle, 1996.

Kâdî İyâz, Ebü'l-Fazl İyâz b. Mûsâ el-Yahsubî. el-ilmâa' ilâ ma'rifeti usûli'rrivâye ve takyîdi's-semâ'. thk. Seyyid Ahmed Sakr. Kahire: Dâru'ttürâs, 1970.

Kandemir, M. Yaşar. "Emâlî”. Türkiye Diyanet Vakfı Islâm Ansiklopedisi. 11/70-71. İstanbul: TDV Yayınları, 1995.

Kandemir, M. Yaşar. "Cüz". Türkiye Diyanet Vakfı İslam Ansiklopedisi. 8/147-148. İstanbul: TDV Yayınları, 1993.

Karataş, Mustafa. İbrahîm b. Abdissamed el-Hâşimî ve "el-Emâlî" İsimli Hadis Cüz'ü. İstanbul: Marmara Üniversitesi, Sosyal Bilimler Enstitüsü, Yüksek Lisans Tezi, 1989.

Kâtib Çelebî. Keş̧ü'z-zunûn an esâmi'l-kütüb ve'l-fünûn. haz. Şerafettin Yaltkaya - Rıfat Bilge. 2 Cilt. Beyrut: Dâru ihyâi't-türâsi'l-Arabî, ts.

Kettânî, Ebû Abdillâh Muhammed b. Ca'fer. Hadis Literatürü. çev. Yusuf Özbek. İstanbul: İz Yayınları, 1994.

Koçak, Faruk. İstanbul Kütüphanelerindeki Hadis Cüzleri. İstanbul: Marmara Üniversitesi, Sosyal Bilimler Enstitüsü, Doktora Tezi, 1995.

Koçyiğit, Talat. Hadis Istılahları. Ankara: AÜ İlahiyat Fakültesi Yayınları, 1980.

Koçyiğit, Talât. Hadis Tarihi. Ankara: TDV Yayınları, 11. Basım, 2019.

Muhammed Abdülcevâd el-Asmaî. "Mukaddime". el-Emâlî. mlf. Ebû Alî İsmâîl b. el-Kâsım el-Kâlî. 1/1-18. 4 Cilt. Kahire: Dâru'l-kütübi'l'ilmiyye, 1970. 
176 | M. TANRIVERDİ / Rivayetlerin Muhafazasına ve Nakline Yönelik Entelektüel Bir İlgi: İmlâ Usûlü ve Hadis Literatürüne Yansımaları

Muhammed Accâc el-Hatîb. es-Sünne kable't-tedvin. Kahire: Mektebetü Vehbe, 1988.

Müeyyedî, Ebü'l-Hüseyin Mecdüddin b. Mansûr el-Hasenî. Levâmi'u'lenvâr. 5 Cilt. Sa'de: Mektebetü't-türâsi'l-İslâmiyye, 1993.

Mürşid Billâh Yahyâ b. el-Hüseyin. Kitâbu'l-Emâlî el-isneyniyye. thk. Abdullah b. Hammûd el-'İzzî. San'a: Müessesetü'l-imâm Zeyd b. Alî es-sekâfiyye, 1429/2008.

Müslim, Ebü'l-Hüseyn Müslim b. el-Haccâc. el-Câmi'u's-sahîh. thk. Muhammed Fuâd Abdulbâkî. 5 Cilt. Beyrut: Dâru'l-kütübi'l'ilmiyye, 1412/1991.

Nesâî, Ebû Abdirrahmân Ahmed b. Şuayb. Cüz' fihi meclisân min imlâ'i (el-Emâlî). thk. Ebû İshâk el-Huveynî el-Eserî. Riyad: Dâru ibni'lCevzî, 1415/1994.

Nevevî, Muhyiddîn Ebî Zekkeriyyâ Yahyâ b. Şeref. İrşâdu tullâbi'l-hakâik ilâ ma'rifeti süneni hayri'l-halâik. thk. Abdü'l-Bârî es-Selefî. Medine: Mektebetü'l-eymân, 1987.

Nureddin Itır. Menhecü'n-nakd fî ulûmi'l-hadîs. Dımaşk: Dâru'l-fikr, 1399/1979.

Okiç, Muhammet Tayyib. Bazı Hadis Meseleleri Üzerine Tetkikler. İstanbul: Osman Yalçın Matbaası, 1959.

Özaslan, Hamza. Ebûu Alî el-Kâlî ve Kitâbü'l-Emâlî. İstanbul: İstanbul Üniversitesi, Sosyal Bilimler Enstitüsü, Yüksek Lisans Tezi, 1996.

Râmhürmüzî, Ebû Muhammed ibn Hallâd el-Hasen el-Fârisî. elMuhaddisü'l-fâsıl beyne'r-râvî ve'l-vâ'̂े. thk. Muhammed Accâc elHatîb. Beyrut: Dâru'l-fikr, 3. Basım, 1984.

S. Ory. "Dār al-Hadith". The Encyclopaedia of Islam (EI'). ed. E. J. Bosworth vd.. 12/195-197. Leiden: Brill Press, 2004.

Sarıçam, İbrahim - Erşahin, Seyfettin. İslâm Medeniyeti Tarihi. Ankara: Türkiye Diyanet Vakfı Yayınları, 2. Basım, 2007.

Sehâvî, Ebü'l-Hayr Şemsüddîn Muhammed b. Abdirrahmân. Fethu'lmuğ̣̂s bi-şerhi Elfiyyeti'l-hadîs. thk. Alî Hüseyin Alî. 5 Cilt. Misır: Mektebetü's-sünne, 1424/2003.

Sem'ânî, Ebû Sa'd Abdülkerîm b. Muhammed b. Mansûr. Edebü'l-imlâ ve'l-istimlâ'. thk. Max Weisweiller. Beyrut: Dâru'l-kütübi'l-'ilmiyye, $1401 / 1981$. 
M. TANRIVERDI / An Intellectual Interest for the Protection and Narration of Hadiths: The Method of Imlā and Its Reflections to Hadith Literature | 177

Seyyid Ahmed el-Hüseynî. Müellefâtü'z-Zeydiyye. 3 Cilt. Kum: Mektebetu Âyetullâhi'l-Uzma, 1413.

Sezgin, Fuat. Târîhu't-türâsi'l-Arabî. çev. Mahmûd Fehmî Hicâzî. 5 Cilt. Riyad: Câmi'atü'l-İmâm Muhammed b. Suûd el-İslâmiyye, 1411/1991.

Suyûtî, Ebü'l-Fazl Celâlüddîn Abdurrahmân. Tedrîbu'r-râvî fî̀ şerh-i takrîbi'n-Nevevî. thk. Muhammed el-Firyâbî. Beyrut: Mektebetü'lkevser, 2. Basım, 1410.

Tanrıverdi, Mustafa. "Ahmed b. Îsâ b. Zeyd ve Emâlî Adlı Hadis Eseri Üzerine Bir İnceleme". Eskişehir Osmangazi Üniversitesi İlahiyat Fakültesi Dergisi 6/11 (Eylül 2019), 309-342.

Tuna, Üzeyir. "Arap Dili ve Edebiyatıyla İlgili Emâlîler". Bayburt Üniversitesi İlahiyat Fakültesi Dergisi 5/9 (Haziran 2019), 117-138.

Uğur, Mücteba. "Edâ". Türkiye Diyanet Vakfı İslâm Ansiklopedisi. 10/388389. İstanbul: TDV Yayınları, 1994.

Uğur, Mücteba. Hadis Edebiyatı. Ankara: TDV Yayınları, 1996.

Yeşil, Ümmügülsüm. "Tashîf ve Tahrîf Üzerine Bazı Mülâhazalar". Hadis Tetkikleri Dergisi 18/1 (Temmuz 2020), 147-156.

Yücel, Ahmet. Hadis Tarihi. İstanbul: MÜ İlahiyat Fakültesi Vakfı Yayınları, 3. Basım, 2011.

Zebîdî, Ebü'l-Feyz Muhammed el-Murtazâ. Tâcü'l-'arûs min cevâhiri'lkâmûs. thk. Komisyon. 40 Cilt. b.y.: Dâru'l-hidâye, ts.

Zehebî, Ebû Abdillâh Şemsüddîn Muhammed. Siyeru a'lâmi'n-nübelấ'. thk. Şuayb el-Arnavûd. 25 Cilt. Beyrut: Müessesetü'r-risâle, 1985.

Zehebî, Ebû Abdillâh Şemsüddîn Muhammed. Târîhu'l-İslâm. thk. Beşşâr Avvâd Ma'rûf. 15 Cilt. Beyrut: Dâru'l-ğarbi'l-İslamî, 2003.

Zemahşerî, Ebü'l-Kâsım Mahmûd b. Ömer el-Hârizmî. el-Keşşâf 'an hakā'ikı ğavâmizı't-tenzîl ve 'uyûni'l-ekâvîl fì vücûhi't-te'vîl. thk. Âdil Ahmed Abdülmevcûd - Alî Muhammed Muavvad. 4 Cilt. Riyâd: Mektebetü'l-ubeykan, 1418/1998.

Ziriklî, Ebû Gays Muhammed Hayrüddîn b. Mahmûd. el-A'lâm: Kâmûsü terâcim. 8 Cilt. Beyrut: Dâru'l-'ilm li'l-melâyîn, 15. Basım, 2002. 